\title{
Emerging Interrelationship Between the Gut Microbiome and Cellular Senescence in the Context of Aging and Disease: Perspectives and Therapeutic Opportunities
}

\author{
Rohit Sharma ${ }^{1}$ D \\ Accepted: 28 December 2021 / Published online: 5 January 2022 \\ (c) The Author(s), under exclusive licence to Springer Science+Business Media, LLC, part of Springer Nature 2022
}

\begin{abstract}
The significance of diversity, composition, and functional attributes of the gut microbiota in shaping human health is well recognized. Studies have shown that gut microbiota is closely linked to human aging, and changes in the gut microbiome can predict human survival and longevity. In addition, a causal relationship between gut microbiota dysbiosis and chronic agerelated disorders is also becoming apparent. Recent advances in our understanding of the cellular and molecular aspects of biological aging have revealed a cellular senescence-centric view of the aging process. However, the association between the gut microbiome and cellular senescence is only beginning to be understood. The present review provides an integrative view of the evolving relationship between the gut microbiome and cellular senescence in aging and disease. Evidence relating to microbiome-mediated modulation of senescent cells, as well as senescent cells-mediated changes in intestinal homeostasis and diseases, have been discussed. Unanswered questions and future research directions have also been deliberated to truly ascertain the relationship between the gut microbiome and cellular senescence for developing microbiome-based age-delaying and longevity-promoting therapies.
\end{abstract}

Keywords Aging $\cdot$ Microbiome $\cdot$ Probiotics $\cdot$ Cellular senescence $\cdot$ SASP $\cdot$ Stress $\cdot$ Immunity

\section{Introduction}

Human beings are considered "metaorganisms" due to our close symbiotic relationship with microorganisms which account for at least half the number of total cells in our body [1]. Most of these microbes are found in the gut, and extensive research has established their central role in maintaining human health and systems by regulating the development and modulation of immune responses [2], host nutrition and metabolism [3, 4], brain development and behavior [5], and the progression of diseases such as cancer [6] and diabetes [7]. Moreover, the identification of an association between altered gut microbiota composition and the magnitude of COVID-19 severity in the ongoing pandemic highlights the importance of gut microbiota in shaping the bodily response

Rohit Sharma

rohit25sharma@gmail.com;

rohit.sharma@shooliniuniversity.com

1 Faculty of Applied Sciences \& Biotechnology, Shoolini University, Solan 173229, India to novel infectious agents [8]. Gut microbiota is abundant in complexity and diversity, and several different microorganisms such as archaea, bacteria, fungi, and viruses reside in the human gastrointestinal tract [9]. The microbiota is maternally acquired at birth [10] and changes throughout the lifespan dominated by dietary habits and environmental signals [11]. Gut microbial heterogeneity amongst communities has also been observed with implications in health and disease $[12,13]$.

Aging has been described as "an unresolved problem of biology" [14], although intensive studies in the past few decades have vastly improved our understanding of the causes and effects of aging. In general, nine "hallmarks of aging" have been identified [15] which ultimately augment the principle that aging is essentially a time-dependent culmination of various cellular and biochemical damage [16, 17]. Cellular senescence is a physiological stress response mechanism that is emerging as one of the most well-characterized hallmarks of aging [18]. Cellular senescence results in the development of senescent cells (SC) which show age-dependent accumulation in tissues and organs of different mammalian species including rodents and primates [19-21]. The increased SC 
burden with age disrupts tissue structure and function and is emerging as a critical factor for increased risk of disease and mortality in the elderly [22, 23]. A breakthrough study demonstrated that the removal of SC burden in aging tissues has the potential to delay the development and severity of age-related pathologies and improve lifespan [24]. Subsequently, molecular targeting of SC using pharmacological interventions showed that $\mathrm{SC}$ can be selectively removed from the organism which resulted in lifespan extension and delayed development of age-related symptoms and diseases [25]. Since then, several natural and synthetic compounds, which selectively target SC (senolytics) have been identified $[26,27]$, and senolytics-based clinical trials are already showing promising results in countering some of the deleterious effects of aging [28-30].

An intricate association between the gut microbiome and organismal aging is increasingly becoming apparent [31]. Since the gut microbiota co-evolves with the host, organismal aging is inevitably accompanied by changes in the gut microbiome [32, 33]. As a result, distinct differences in the microbial composition, as well as the functional aspects of the microbiome between young and elderly human subjects, have been observed [34-36]. However, the interrelationship between the gut microbiome and cellular senescence in regulating the process of aging and related diseases is only beginning to be understood. In the present manuscript, I provide an overview of cellular senescence and gut microbiota in driving the aging process and then review the available evidence linking the two phenomena. Possible therapies and future directions to better understand the causal relationship between cellular senescence and gut microbiota in governing organismal aging is also presented.

\section{Cellular Senescence Links Biological Aging}

\section{Characteristics of Cellular Senescence}

Cellular senescence is a physiological stress response mechanism in mammalian cells characterized by irreversible cell cycle arrest mediated by activation of cell cycle inhibitor pathways (p53/p21 and/or p16 $6^{\text {Ink4a }} / \mathrm{pRb}$ ), DNA damage, chromatin remodeling, senescence-associated $\beta$-galactosidase (SA- $\beta$-gal) activity, changes in metabolic signaling pathways (mTOR/AMPK), impaired mitochondrial reactive oxygen species (ROS) production, cellular hypertrophy, and the development of characteristic senescence-associated secretory phenotype (SASP) [37, 38]. The connection between aging and cellular senescence was initially based on the observation that SC tend to accumulate in aging tissues [39]. However, SC develop naturally and their crucial role in regulating processes such as wound healing and embryonic tissue remodeling has also been documented [40, 41]. Today, it is accepted that age-related accumulation of SC, and not SC per se, is responsible for the increased age-related pathologies and decreased health span and lifespan [42]. It is argued that cellular senescence evolved as a mechanism to protect against tumorigenesis in cells exposed to chronic stress-induced damage [43], as opposed to apoptosis which is activated in response to acute stressors $[44,45]$. In younger organisms, the SASP factors secreted by SC chemotactically attract the cells of the immune system such as macrophages, NK cells, or cytotoxic T cells which then recognize SC through specific cell surface receptors ultimately resulting in their elimination [46]. However, as organisms age, a tissue-specific and non-linear accumulation of SC is observed that eventually impairs organ functions [47, 48]. The chronic secretion of SASP components, which are a milieu of several cytokines and growth factors, by accumulating SC plays a particularly deleterious role by rendering harmful bystander effects on nearby healthier cells ultimately promoting pro-inflammatory and pro-tumorigenic behavior [49] (Fig. 1). Thus, SC, which are evolutionarily considered anti-tumorigenic, ultimately render the aging organism more prone to cancerous and inflammatory disorders in a classic case of antagonistic pleiotropy [50]. Corroborating this, a wealth of data has shown that targeting the development of cellular senescence during aging improves longevity and healthspan, suppresses inflammatory disorders, enhances organ functioning, while transplantation of SC can provoke disease conditions in healthy animals [24, 51-54].

\section{Cellular Stress and Cellular Senescence}

The development of cellular senescence is intimately linked to cell-intrinsic and extrinsic stressors [55]. Cellautonomous (intrinsic) stress could be attributed to replicative stress, mitochondrial dysfunction, autophagic dysregulation, and proteostasis, while external stressors include metabolic stress, heat, genotoxic agents, and heavy metals. It has been shown that during aging, the natural stress response is impaired [56], which, combined with chronic exposure to stressors, result in perturbations in mitochondrial redox balance, energy production, and aggravation of inflammatory pathways [57]. This can result in a vicious loop wherein damaged mitochondria produce more free radicals, and this sustained redox pressure further damages macromolecules and initiate DNA damage response that propels cells into the state of permanent cell cycle arrest and SASP, thereby hampering tissue and organ functions characteristic of aging [45] (Fig. 1). Thus, premature stress-induced models of cellular senescence have been successfully used in in vitro studies. While other stressors may be indefinite and subject to regulation, replicationinduced stress is a fundamental feature of mitotic cells that gradually contributes to the development of replicative 
Fig. 1 Overview of the development and accumulation of senescent cells during aging. Chronic stressors (oxidative/ replicative/oncogenic), reduced cellular stress response capacity, and impaired immune functions can augment the development and accumulation of senescent cells in various tissues. Persistent senescent cells develop SASP which affect nearby healthier cells through paracrine mechanisms, promote inflammatory and tumorigenic environment and ultimately impair organ functions, and promote the aging phenotype. Illustration created at app.biorender.com

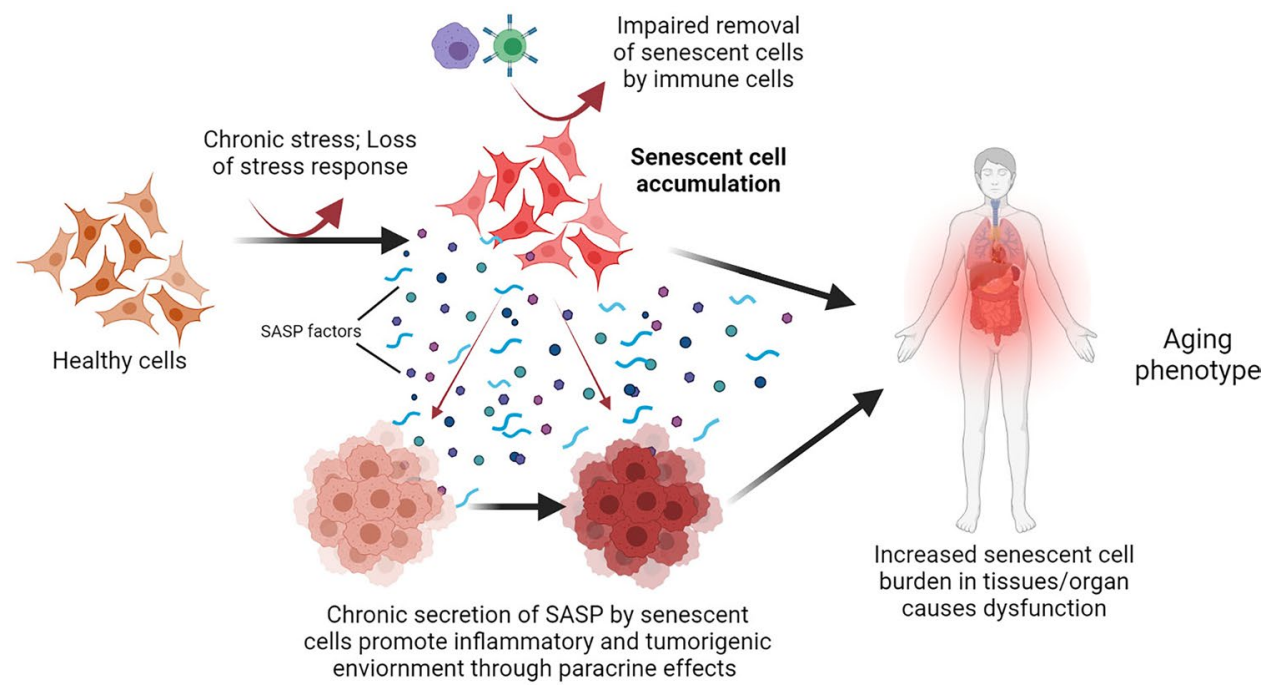

cellular senescence [58]. Replicative stress arises because, during each cell division, chromosomes lose a part of their protective telomere cap, and with each successive division, telomeres become too short to sustain further replication resulting in activation of the cellular senescence program [58]. However, it is interesting to note that oxidative stress can also accelerate telomere attrition suggesting that the chronic presence of different stressors can rapidly induce/ augment different (oxidative/replicative/oncogenic) senescence programs in cells $[59,60]$.

Although the development of SC is relatively better understood, however, the exact causes for the age-dependent increase in tissue SC burden are yet unclear. Recent studies have shown that the accumulation of SC in tissues is not linear, but accelerates with age, suggesting that a threshold barrier may exist beyond which SC accumulation exponentially rises [48, 61]. The immune system is rapidly emerging as a critical regulator of the apparent age-associated SC accumulation. A recent study conclusively demonstrated that immune cells with dysfunctional cytotoxic ability exhibit inefficient clearance of SC in vivo resulting in their accumulation and augmentation of inflammatory disorders [62]. This study advanced the idea that deleterious widespread functional and phenotypic changes in aging immune cells (immunosenescence) can result in impaired immunosurveillance and cytotoxic effector functions that may promote $\mathrm{SC}$ accumulation [46]. However, the situation gets further compounded by the fact that similar to other cells, immune cells also undergo cellular senescence with age, and thus, their efficacy in clearing SC may be subject to regulation by both immunosenescence and cellular senescence [63-65]. Surprisingly, a recent study demonstrated that similar to tumorous cells, SC can also develop immune evasive properties which may augment their survival and persistence in tissues thereby indicating a deeper relationship between host immunity and SC [66]. Taken together, it is evident that accumulation of SC is harmful, and strategies aimed at prevention or regression of cellular senescence during aging are desirable to alleviate morbidity and mortality in the elderly [67].

\section{Gut Microbiota in Aging and Associated Diseases}

\section{Gut Dysbiosis Affects Healthspan and Lifespan}

Alterations in the diversity and composition of the gut microbiota (gut dysbiosis) with advancing age affect metabolism and immune regulation that predispose the elderly to oxidative and inflammatory disorders [68, 69]. Therefore, maintenance of homeostatic balance in the intestinal microbiota is beneficial for the host, and any perturbations in microbial community structure that induce an imbalance between commensal gut microbes and opportunistic pathogens can render the gut vulnerable to damage and loss of intestinal homeostasis. The altered gut microbial state can be attributed to the loss of beneficial organisms, the proliferation of harmful pathogenic genera, or an overall decrease in microbial diversity [70]. For instance, studies have shown that age-related gut dysbiosis generally results in enhanced growth of facultative anaerobes, decreased numbers of beneficial probiotic bacterial species, and altered firmicutes/ bacteroidetes ratio [71, 72]. There is enough evidence available to suggest a correlation between gut dysbiosis, longevity, and the prevalence of chronic disorders [73-75]. A recent report highlights that gut microbiome composition is a predictor of human survival and increased abundance of Bacteroides or low gut microbiome uniqueness is associated with decreased lifespan and enhanced morbidity [76]. 
Further, based on machine learning, another recent report inferred that the taxonomic profile of the gut microbiota can also be used to precisely predict the chronological age of an individual thereby advocating the concept of a microbiotabased aging clock [77]. This is a significant finding which highlights a profound association between host microbial community structure and lifespan while also providing potential therapeutic implications. However, it is noteworthy that although all individuals undergo programmed chronological aging, the rate of biological aging varies markedly. Biological aging essentially refers to the understanding of disease-independent pathophysiological changes and molecular markers which contribute to characteristic aging phenotype and morbidity in the elderly. Biological aging is thus argued as a more comprehensive and reliable predictor of the deleterious effects of aging as well as the development of mitigating therapies $[78,79]$. In this regard, there is some evidence that decreased gut microbial diversity may be correlated with the "frailty index" which is considered a predictor of the biological age and healthspan [80, 81]. However, the relationship between gut dysbiosis and longevity is relatively well studied. For example, it has been shown that dysbiosis in the commensal bacterial population shortens the lifespan in Drosophila [82], while colonizing the gut of middle-age African turquoise killifish with bacteria isolated from young donors resulted in lifespan extension and delayed behavioral decline [83]. Microbiota transplantation studies have demonstrated that the altered gut microbiome of the elderly is sufficient to induce morbidity in young recipients and thus affect the healthspan. For instance, it was observed that transplantation of the gut microbiota from aged mice to germ-free mice promoted inflammation in the small intestine and enhanced the leakage of inflammatory bacterial components into circulation which were correlated with higher levels of TM7 bacteria and Proteobacteria [84]. A recent study demonstrated that fecal microbiota transplantation from aged murine donors led to impaired spatial learning and memory in young adult recipients accompanied by a strong reduction of short-chain fatty acids (SCFAs) producing bacteria such Lachnospiraceae, Faecalibaculum, and Ruminococcaceae [85]. Similarly, fecal transplant gavages from old mice (but not young mice) to germ-free mice showed decreased fecal SCFA production, and recipient animals demonstrated depressive-like behavior, impaired short-term memory, and spatial memory suggesting that aged microbiome alone is sufficient to decrease SCFAs in the host and to produce cognitive decline [86]. Similarly, fecal microbiota transplantation from old to young rats impaired cognitive behavior, decreased regional homogeneity, changed synaptic structures, increased glycation-end products, and enhanced oxidative and inflammatory stress in recipient young animals [87]. Further, a single-center clinical trial recommended fecal microbiota transplantation as a home therapy that could clinically benefit recovery in elderly patients with Clostridium infection [88]. On the contrary, it has been reported that transplanting the gut microbiota of healthy old donor mice into young germ-free recipient mice enhanced hippocampal neurogenesis, intestinal growth, and activated the longevity FGF21-AMPK-SIRT1 signaling pathways in the liver which was attributed to the increased presence of butyrate-producing microbes [89]. In this regard, another study has shown that although aging in healthy donors is associated with compositional alterations in the fecal microbiome, the overall microbial diversity and effectiveness of fecal microbiota transplantation may still be preserved [90]. However, despite heterogenic variations in different experimental conditions, it is evident that beneficial effects of desirable bacterial populations, such as butyrateproducing microbes, may be useful in protection against age-associated morbidity. Taken together, it can be argued that the gut microbial profile is intricately associated with chronological as well as biological aging thereby signifying its critical importance in shaping human lifespan and healthspan. In addition, it is important to note that aging not only influences the gut microbiota composition, but is also associated with changes in the gut lumen and barrier functions such as shrinkage of the protective mucus layer of the gut, loss of intestinal tight junction proteins, and increased permeability of the epithelial barrier [91, 92]. As a result, bacteria and/or their metabolites can escape the gut lumen which may provoke immune cells in the Peyer's patches of lamina propria, and further augment systemic inflammation if translocated into peripheral circulation [93] (Fig. 2).

\section{Gut Dysbiosis and Age-Related Disorders and Conditions}

The relationship between gut dysbiosis and the risk of agerelated chronic disorders is also rapidly gaining attention [94, 95]. For instance, the development of type II diabetes is associated with the gut microbiome which has been shown to modulate the diabetogenic effects by affecting glucose metabolism, energy expenditure, inflammation, and gut permeability [96]. A recent report has demonstrated that type II diabetes is associated with widespread compositional changes in the gut microbiome of urban Africans [97]. Further, studies have also revealed that altered microbiota composition during type II diabetes is characterized by a decrease in anti-inflammatory and probiotic bacterial species, while an increase in potentially pathogenic bacteria has also been observed [98, 99]. However, it must be noted that due to the heterogenic and multifactorial origin and effects of type II diabetes, conclusive evidence implicating specific microbes in the pathogenesis of the disease is challenging and remains elusive. Host microbiome is also rapidly emerging as a predictor of severity and therapy outcomes in several 
Fig. 2 Schematic diagram depicting the influence of aging on gut homeostasis. Dominated by diet and environmental factors, aging induces structural and functional changes in the gut microbiota resulting in a dysbiotic gut. The altered metabolome of the dysbiotic gut, shrinkage of the protective mucus layer, and loss of tight junction proteins promote "leakage" through the gut barrier. Bacteria as well as bacterial components, such as LPS and flagella, can translocate through the "leaky gut" and reach lamina propria resulting in activation of immune cells in the Peyer's patches, and can also cause systemic inflammatory aggravation through peripheral circulation. Illustration created at app.biorender.com

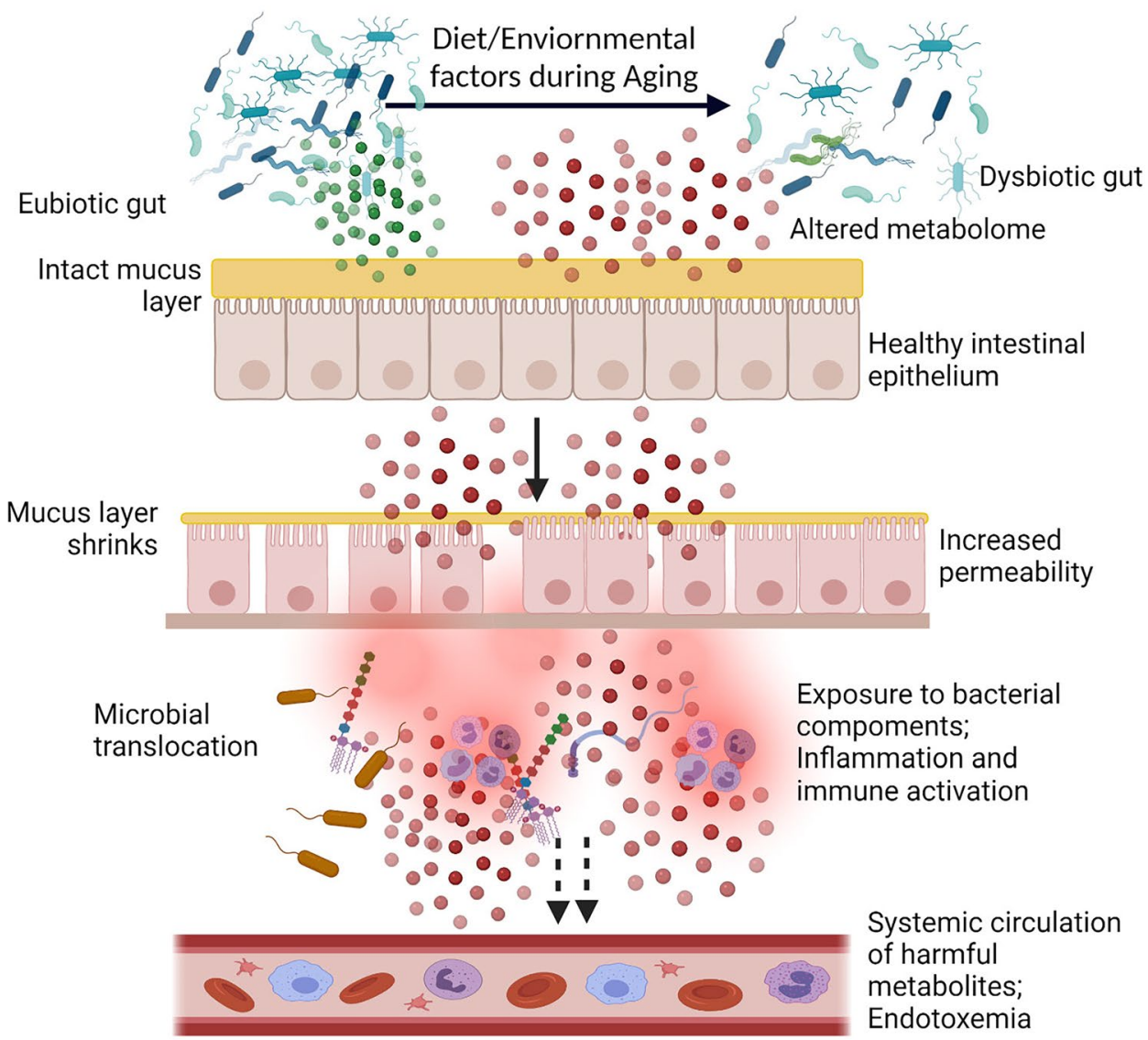

incidences of cancers [100, 101]. Numerous studies have shown altered gut microbiota composition during the development of various cancers including but not limited to colorectal cancer [102], gastric cancer [103], lung cancer [101], pancreatic cancer [104], prostate cancer [105], breast cancer [106], brain cancer [107], and even leukemia [108]. Mechanistically, the gut microbiome can influence tumorigenesis at sites distant to the gut by regulating circulatory levels of metabolites and nutrients as well as through the release of microbial toxins which are currently under intense investigation [109]. Changes in the gut microbiota community have also been documented in the pathogenesis of age-related cardiovascular disorders such as heart failure and coronary artery diseases. In general, decreased abundance of butyrateproducing bacteria such as Faecalibacterium, Roseburia, and Eubacterium rectale has been observed in patients with coronary heart disease [110-112], as well as in patients with chronic heart failure and cardiac insufficiency [73, 113, 114]. While the mechanisms of the pathogenesis of gut microbiome dysbiosis in the generation of cardiovascular disorders are yet unclear, age-related increase in intestinal permeability and subsequently increased diffusion of harmful bacterial metabolites that result in sustained inflammation have been considered. For example, increased circulatory levels of microbe-dependent trimethylamine- $\mathrm{N}$-oxide have been observed in patients with heart failure which was also correlated with increased risk of mortality and the development of cardiovascular disorders $[115,116]$. Taken together, it is reasonable to assert that the role and relevance of gut microbiota in the pathogenesis of some of the defining agerelated disorders of twenty-first century, i.e., type II diabetes, cancer, and cardiovascular diseases, is a significant emerging phenomenon that should not be overlooked [117].

In addition to chronic disorders, gut dysbiosis also appears to play a significant role in the development of age-associated natural yet deleterious processes such as immunosenescence and inflamm-aging [118, 119]. Immunosenescence is an umbrella term that describes age-dependent restructuring of the immune system which strongly determines the known alterations in immune response and functions in the elderly [120]. Despite its name, immunosenescence does not cause a global suppression of the immune functions since phenomenon such as increased systemic inflammation (inflamm-aging) is also observed in the elderly. According to the integrated immunological theory of aging, immunosenescence forms the 
basis of the development of age-associated systemic oxidative and inflammatory stress (oxi-inflamm-aging) which renders the elderly susceptible to increased risk of morbidity [121]. Moreover, strong evidence is now emerging that immunosenescence may be directly responsible for the accumulation of SC in vivo and thus could be a potential therapeutic target $[62,65,122]$. A direct link between the gut microbiota and immunosenescence of blood neutrophils through the regulation of TLR and MYD88 signaling pathways has been reported [123]. Authors observed that the depletion of the gut microbiota significantly attenuated the numbers of circulatory aged neutrophils, while the addition of LPS through intragastric gavage completely restored the numbers of neutrophils suggesting that leakage of bacterial components through the aging gut can drive neutrophil aging [123]. A recent study demonstrated that gut microbiota changes in young adulthood (32-42 years of age) may be associated with major metabolic, immunological, and inflammatory parameters which could be useful in detecting accelerated aging [124]. A report on healthy middle-aged and old-aged human subjects showed a quantitative and qualitative correlation between the composition of the gut microbiota and the markers of immunosenescence [125]. Another study demonstrated that exposing aged mice to the microbiota from young mice dramatically improved M-cell maturation in the intestine of the aged mice and increased antigen uptake and IgA responses suggesting a novel role of gut microbiota in enhancing M-cell mediated immunosurveillance and vaccine efficacy in the elderly [126]. It must be noted that the gut microbiota and the host immune system have co-evolved to allow the existence of commensal bacteria through immune tolerance, and there is evidence that the deleterious effects of immunosenescence may also be linked to an abnormal immune response against gut microbes due to dysbiosis or decreased tolerance [127]. Interestingly, we have previously observed that dietary supplementation of probiotic fermented milk in aged mice can mitigate several aspects of immunosenescence through the suppression of inflamm-aging, improvement in Th1/Th2 immune balance, and robust immune response to pathogenic Escherichia coli [128].

\section{Gut Microbiome and Cellular Senescence}

A bidirectional relationship between the gut microbiome and cellular senescence can be envisaged wherein secretory metabolites of the gut microbiota mediated bio-transformed dietary components can directly impact cellular senescence in intestinal cells, while the accumulating senescent cells (epithelial/fibroblasts) in the intestine (and SASP thereof) may contribute to altered cellular functions and immune activation in the gut (Fig. 3).

\section{Microbiota Metabolites and Cellular Senescence}

The gut microbiome utilizes dietary fuel to synthesize an array of bioactive metabolites such as SCFAs, phenols, neurotransmitters, HPA hormones, endotoxins, and ammonia through processes such as microbial fermentation [129]. These metabolites can reach circulation and affect the functioning of distal organs and systems [130, 131], and as such, the gut microbiome is often considered a complex virtual endocrine organ [132]. Although cellular senescence is subject to several regulations, however, the natural development of cellular senescence can be regulated by cells' ability to counter ROS-mediated oxidative damage and stress response capacity [133]. Indeed, it has been demonstrated that increased oxidative stress over the lifespan of an animal can directly enhance the accumulation of SC [134], and the application of antioxidants can attenuate cellular senescence both in vitro and in vivo $[135,136]$. Therefore, it is conceivable that the development and accumulation of SC can be attenuated or delayed either by enhancing the potency of cellular stress response and/or redox balance or simply by neutralizing the external oxidative/inflammatory stressors. In this regard, diverse metabolites of the gut microbiome and probiotic bacteria, or microbiome-fermented dietary phytomolecules are known to exert strong anti-inflammatory and antioxidant attributes which may be useful in preventing senescence-associated pro-inflammatory and pro-tumorigenic environment [137-142] (Fig. 3). Moreover, complex phytomolecules, especially polyphenols, which are poorly absorbed in the small intestine, are fermented by the colon microbiota to yield several simpler molecules which may have different and/or enhanced biological effects than the original compound [138, 143, 144]. We have also observed that amalgamation of probiotic bacteria and tea polyphenol EGCG can differentially modulate the aging immune system as compared to individual treatments of constitutive elements [145]. However, our recent work provided the first evidence of suppression of stress-induced premature cellular senescence by the application of probiotic bacteria. It was observed that metabolites secreted by a probiotic Lactobacillus fermentum, isolated from human fecal matter, can attenuate multiple characteristic markers of senescence in preadipocytes such as cellular hypertrophy, SA- $\beta$-gal activity, induction of SASP, DNA damage response, Akt/mTOR pathway, and activation of cell cycle inhibitor signaling [146]. Using a reconstructed skin model, another study reported that extract of bacterium Sphingomonas hydrophobicum can delay skin senescence by attenuating the activation of $\mathrm{p} 21, \mathrm{p} 16^{\text {Ink4a }}$ cell cycle inhibitors, and SA- $\beta$-gal activity resulting in restructuring of skin as well as psychobiological effects [147]. It is thus conceivable that secretory factors of the gut microbiota 
Fig. 3 Relationship between the gut microbiome and senescent cells. (1) Metabolites of the microbiome or those produced by microbial biotransformation of dietary components, can directly influence cellular stressors and stress response capacity which can ultimately attenuate the development and progression of cellular senescence. (2) Cellular senescence can contribute to functional dysfunctions in the intestinal cells, and SASP secreted by these cells can augment aberrant intestinal inflammation, immune cell activation, and gut dysbiosis. Illustration created at app.biorender.com

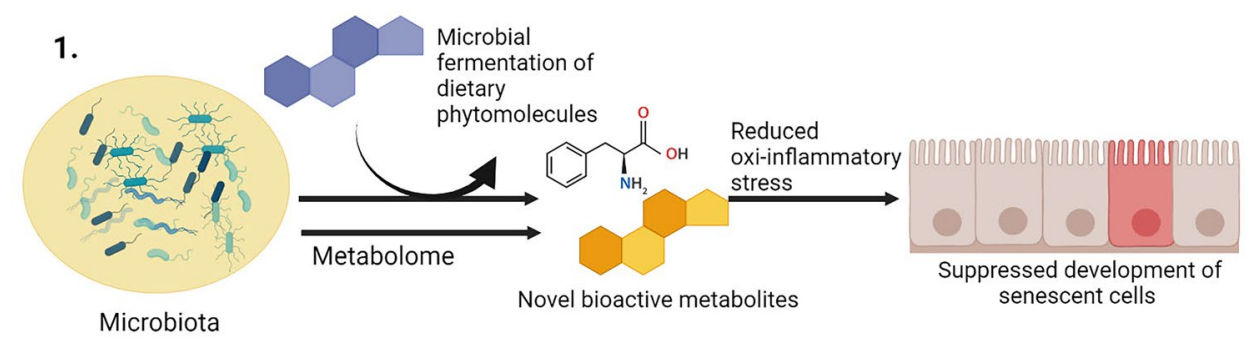

2.

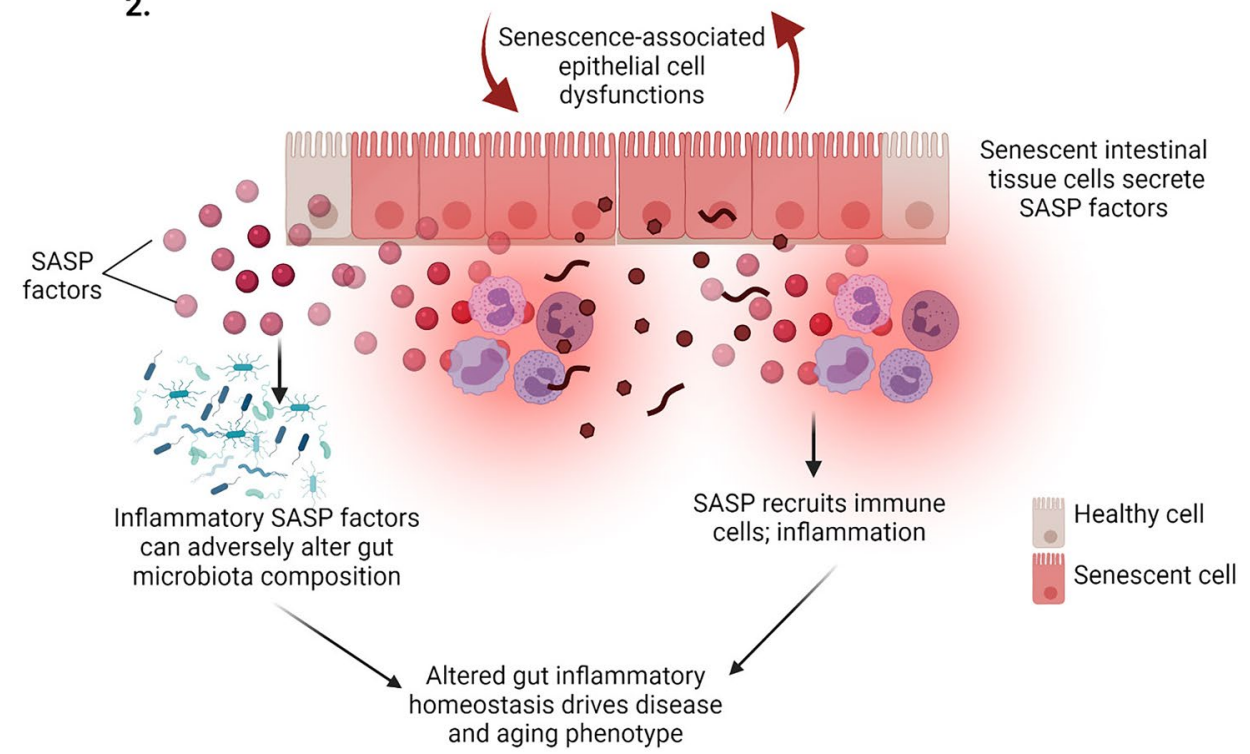

can influence cellular senescence, although further in vivo studies are warranted.

\section{Senescent Intestinal Cells Can Impact Gut Inflammatory and Microbial Homeostasis}

Cells of the intestinal tissue such as the intestinal epithelial cells (IECs) and subepithelial fibroblasts not only act as a protective barrier that separates the host tissues from the luminal environment but also serve as sensors to maintain inflammatory homeostasis in the gut. Age-related progressive increase in SC burden and chronic SASP environment in the intestinal tissue can dysregulate the normal functioning of IECs (such as barrier functions) and ultimately contribute to increased gut permeability and enhanced susceptibility to inflammation and infections (Fig. 3). A recent analysis showed an age-dependent increase in senescent $\mathrm{p} 16^{\text {Inka4a }}+/ \mathrm{p} 21+$ cells in various human organs, including the colon tissues, suggesting SC accumulation as a function of intestinal aging across the human lifespan [47]. Similarly, another report revealed that intestinal tissue developed strong signatures of cellular senescence as evident by increased expression of senescence markers- $\mathrm{p} 16^{\text {Ink4a }}$, p $21^{\text {Cip1 }}$, and SA- $\beta$-gal activity in both WT mice and accelerated aging mice model $-E_{r c c l}{ }^{-/ \Delta}[148]$. We also observed an age-dependent increase in DNA damage, cellular senescence ( $\left.\mathrm{p} 53 / \mathrm{p} 21^{\mathrm{WAF} 1}\right)$, activation of SASP regulators (NFKB, p38MAPK, Cox-2), and metabolic stress in the intestinal tissue of aged mice indicating their vulnerability to spontaneous age-related genotoxic stress [149]. In addition, intestinal epithelial organoids derived from aged mice also showed consistent upregulation of senescence markers such as SA- $\beta$ gal activity and p21 as compared to organoids derived from younger organisms [150]. Intestinal epithelial stem cells of old mice expressed enhanced mRNA levels of genes associated with cellular senescence and oxidative stress [151], and radiation exposure also induced premature cellular senescence and SASP phenotype in intestinal stem cells in vivo [152]. It is thus evident that intestinal epithelial, as well as stem cells, exhibit age-dependent cellular senescence which can contribute to known functional alterations and disruption of gastrointestinal homeostasis. Moreover, the chronic SASP secreted by senescent intestinal cells can promote inflammatory environment and/or oncogenic transformation which can have harmful effects on gut permeability, immune activation as well as gut microbiome composition $[149,152]$ 
(Fig. 3). A breakthrough study demonstrated the effects of a dysbiotic gut in the development of SASP and its deleterious effects. It was observed that obesity-induced alterations in the gut microbiota can augment the synthesis of a genotoxic bacterial metabolite- deoxycholic acid (DCA), which provokes SASP phenotype in stellate hepatic cells, ultimately inducing a pro-inflammatory environment and aiding in the development of hepatocellular carcinoma (HCC) in mice [153]. Remarkably, blocking DCA production or antibioticmediated reduction in gut bacteria efficiently prevented HCC development in obese mice [153]. Another study reported the role of senescent colon tissue environment, including the SASP, in the pathogenesis of age-related disease of colorectal cancer [154]. Authors observed increased numbers of senescent stromal cells in the colon stroma and identified GD15 as a key SASP factor secreted by senescent colon cells which augmented cell proliferation, migration, and invasion in colon adenoma; CRC cell lines; and primary colon organoids via the MAPK and PI3K signaling pathways [154]. It is also worth noting that although cellular senescence is seemingly undesirable in the context of aging; yet pro-senescence strategies are often considered favorable for preventing the proliferation of cancerous cells [155]. In this context, bacterial metabolites such as butyrate have shown the potential to limit the proliferation of cancerous cells by upregulating the expression of pro-senescence genes such as p21, p27, and SASP regulators [156, 157], and suppressing genotoxic risk factors of cancer development [158, 159].

\section{Are Anti-senescence Effects of Dietary Food Components Mediated Through the Gut Microbiota?}

A wealth of emerging data has demonstrated that nutraceuticals, especially phytomolecules can attenuate several aspects of cellular senescence and SASP [160]. Given that these dietary components first interact with the gut microbiome, it is plausible to envisage that the known anti-cellular senescence or other age-associated health beneficial effects of nutraceuticals may also be related to the modulation of the gut microbiome and gut metabolites thereof [161, 162]. For instance, the mechanisms of anti-cellular senescence and senolytic attributes of putative senolytics such as quercetin, EGCG, resveratrol, and fistein are incompletely understood and could be mediated by influencing the composition of the gut microbiome [163]. This is especially plausible given the fact that bioactive phytomolecules can promote the proliferation of probiotic bacteria, suppress the growth of pathogenic bacteria, and also act as second-generation synbiotics $[145,164]$. A recent report has demonstrated that the consumption of a senolytic combination of Dasatinib (D) and Quercetin $(\mathrm{Q})$ resulted in lower SC burden (p16 ${ }^{\text {Inka4a }}$ and p21 expression) and SASP phenotype (Cxcl1, IL1 $\beta$, IL6, MCP1, and $\mathrm{TNF}-\alpha$ expression) in the small and large intestine as compared with control mice. Remarkably, specific microbial populations in ileal, cecal, colonic, and fecal regions were also distinctly modulated by $\mathrm{D}+\mathrm{Q}$, suggesting that senolytics might improve health via reducing intestinal senescence, inflammation, and gut microbial dysbiosis in older subjects [163]. Our recent report also observed that dietary consumption of another putative senolytic, green tea EGCG, decreased SC burden in multiple tissues which correlated with increased suppression of pathogenic bacteria in the gut microbiome of aged mice [149]. Another natural senolytic fistein, which is abundant in numerous fruits and vegetables, can suppress premature ovarian failure [165] and agerelated Parkinson's disease by regulating the composition of gut microbiota [166]. Further, polyphenols quercetin and resveratrol can enhance in vivo microbial diversity, especially related to beneficial probiotics such as Lactobacillus and Bifidobacterium, and augment intestinal inflammatory homeostasis [167-169]. Similar to polyphenols, few studies have shown that dietary supplementation of probiotic bacteria can also influence inflammatory disorders through the modulation of cellular senescence in colon tissue. For example, administration of Lactobacillus pentosus var. plantarum C29 to aged rats inhibited inflamm-aging, improved expression of gut tight junction proteins, and bacterial diversity which correlated with suppression of cellular senescence in the colon of aged rats [170]. Similarly, consumption of probiotic Lactobacillus brevis OW38 in experimental animals inhibited cellular senescence in the colon, and reduced the ratio of Firmicutes or Proteobacteria to Bacteroidetes [171], while consumption of a probiotic mixture IRT5, containing five different probiotic strains, attenuated multiple aspects of age-dependent colitis in rats by targeting cellular senescence and inflammatory aggravation [172].

\section{Future Research Directions}

There are several deficiencies and unanswered questions in our current understanding of the interrelationship between gut microbiota and cellular senescence (Fig. 4). Emerging evidence suggests that the gut metabolome could be a more pragmatic and functional marker of a healthy gut [173] since traditional metagenomic-based approaches lack quantitative functional annotation [174]. Recent observations suggest that gut metabolome analyses can effectively reveal microbiome-dependent interactions between diet and metabolites, as well as ethnic and disease conditions [175-177]. However, studies delineating the role of gut metabolome alterations with lifespan and diseases are limited and are only beginning to be understood [178, 179]. Since there is evidence that secretory metabolites of commensal bacteria can directly modulate SC development [146], it would be interesting to assess how age-dependent gut metabolome 
Fig. 4 Open questions and opportunities relating gut microbiome and cellular senescence. (1) How the gut metabolome changes with age, and how it could be related to cellular senescence and SASP is not known. (2) Whether the known effects of senolytics and anti-senescence agents are mediated through gut microbiome modulation is not clear. (3) How does SASP of accumulating senescent cells in the intestine can affect the diversity and composition of gut microbiome remains to be completely elucidated. Illustration created at app.biorender.com

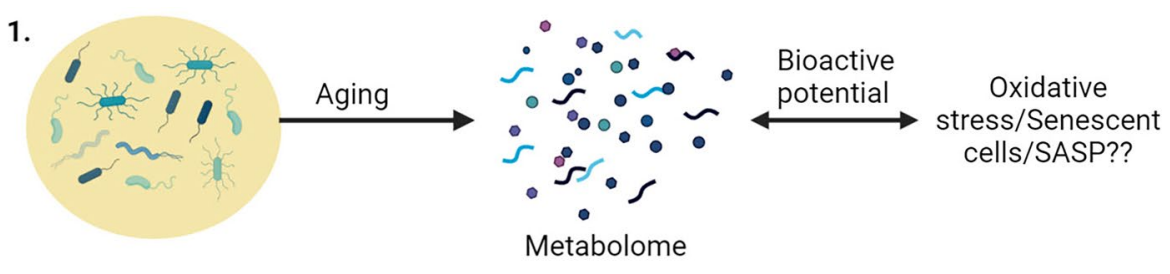

2. Senolytics/Anti-senescence agents/Probiotics Gut Microbiome/
Immunosenescence ?? Senescent cell burden

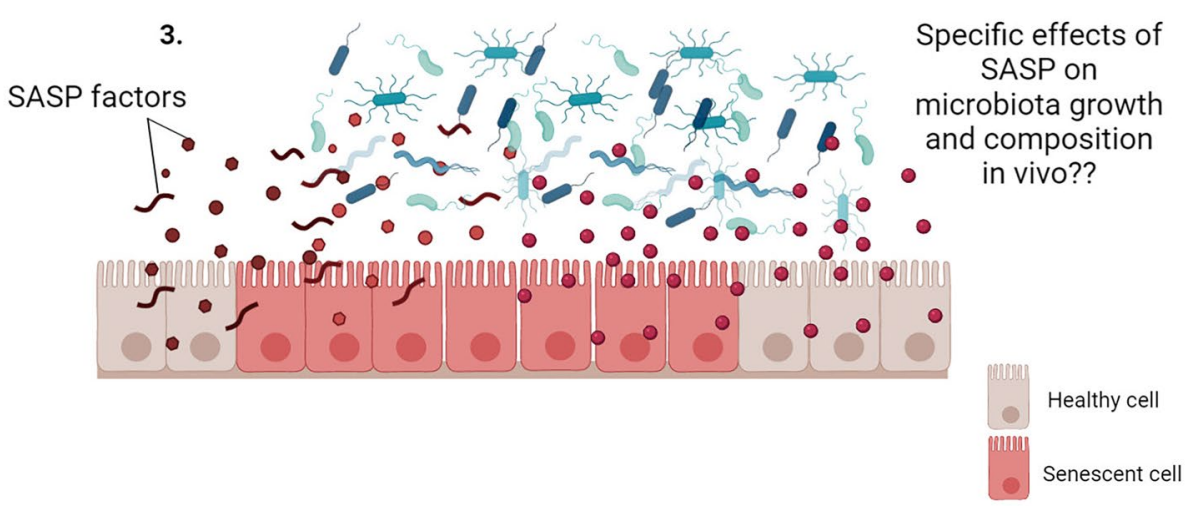

changes affect the oxi-inflammatory stress in the gut, and whether these changes could be correlated with increased SC burden in the intestine (Fig. 4). Secondly, there is an acute dearth of information on whether the effects of putative anticellular senescence agents or senolytics and senomorphics could be related or even dependent on the modulation of the gut microbiome. This is significant since a particular focus amongst gerontologists is on identifying/developing diet-based senolytics, but their relationship with the gut microbiome is not clear. Moreover, probiotic bacteria, which have been ardently augmented as modulators of gut dysbiosis [180], are yet to be conclusively assessed for their anti-cellular senescence attributes per se (Fig. 4). Thirdly, it is essential to ascertain the direct biological impact of the SASP prevalent in senescent intestinal tissue cells in influencing the microbiota diversity and composition during aging (Fig. 4). This may be tested by studying SC and their secretome on the growth and abundance of specific microbial populations or a milieu of different representative microbes. Finally, we know the impact of microbiota in the development and maturation of the immune system, and thus it is reasonable to speculate that strategies targeting gut dysbiosis could also improve immune functions during aging which may help counter SC burden and SASP development. However, as of now, this is purely speculative and further research is required to comprehend the relationship between age-related dysbiosis and immunosenescence vis-à-vis cellular senescence [181].

\section{Conclusions}

The gut microbiome is considered as an additional organ in our body with epigenetic effects on health and physiology [182]. It is accepted that gut microbiota and human aging are intimately linked; however, our understanding of the aging process per se is yet incomplete and is being progressively deciphered. Despite its limitations, cellular senescence is currently the focus of aging research [183], which, combined with immunosenescence and gut dysbiosis, together form the major known contributors to the process of aging and its deleterious effects. Given this emerging paradigm, it is essential that the gut microbiome and aging be investigated in the emerging purview of cellular senescence, SASP, and immunosenescence, which bears the promise to identify new therapeutic targets for microbiome oriented anti-aging interventions. 
Funding This work was supported by a grant from the Department of Science and Technology, Government of India under the INSPIRE Faculty scheme (grant no. IFA17-LSPA79).

\section{Declarations}

Ethical Approval This article does not contain any studies with human participants or animals performed by any of the authors.

Conflict of Interest The authors declare no competing interests.

\section{References}

1. Sender R, Fuchs S, Milo R (2016) Revised estimates for the number of human and bacteria cells in the body. PLoS Biol 14:e1002533e1002533. https://doi.org/10.1371/journal.pbio.1002533

2. Schluter J, Peled JU, Taylor BP, Markey KA, Smith M, Taur Y, Niehus R, Staffas A, Dai A, Fontana E, Amoretti LA, Wright RJ, Morjaria S, Fenelus M, Pessin MS, Chao NJ, Lew M, Bohannon L, Bush A, Sung AD, Hohl TM, Perales M-A, van den Brink MRM, Xavier JB (2020) The gut microbiota is associated with immune cell dynamics in humans. Nature 588:303-307. https:// doi.org/10.1038/s41586-020-2971-8

3. Goodrich JK, Davenport ER, Waters JL, Clark AG, Ley RE (2016) Cross-species comparisons of host genetic associations with the microbiome. Science 352:532-535. https://doi.org/10. 1126/science.aad9379

4. Kaoutari AE, Armougom F, Gordon JI, Raoult D, Henrissat B (2013) The abundance and variety of carbohydrate-active enzymes in the human gut microbiota. Nat Rev Microbiol 11:497-504. https://doi.org/10.1038/nrmicro3050

5. Smith PA (2015) The tantalizing links between gut microbes and the brain. Nature 526:312-314. https://doi.org/10.1038/526312a

6. Sobhani I, Bergsten E, Couffin S, Amiot A, Nebbad B, Barau C, de'AngelisRabot NS, Canoui-Poitrine F, Mestivier D, Pédron T, Khazaie K, Sansonetti PJ (2019) Colorectal cancer-associated microbiota contributes to oncogenic epigenetic signatures. Proc Natl Acad Sci USA 116:24285-24295. https://doi.org/10.1073/ pnas.1912129116

7. Li Q, Chang Y, Zhang K, Chen H, Tao S, Zhang Z (2020) Implication of the gut microbiome composition of type 2 diabetic patients from northern China. Sci Rep 10:5450. https://doi.org/ 10.1038/s41598-020-62224-3

8. Yeoh YK, Zuo T, Lui GC-Y, Zhang F, Liu Q, Li AY, Chung AC, Cheung CP, Tso EY, Fung KS, Chan V, Ling L, Joynt G, Hui DS-C, Chow KM, Ng SSS, Li TC-M, Ng RW, Yip TC, Wong GL-H, Chan FK, Wong CK, Chan PK, Ng SC (2021) Gut microbiota composition reflects disease severity and dysfunctional immune responses in patients with COVID-19. Gut 70:698-706. https://doi.org/10.1136/gutjnl-2020-323020

9. Ferreiro A, Crook N, Gasparrini AJ, Dantas G (2018) Multiscale evolutionary dynamics of host-associated microbiomes. Cell 172:1216-1227. https://doi.org/10.1016/j.cell.2018.02.015

10. Dominguez-Bello MG, Costello EK, Contreras M, Magris M, Hidalgo G, Fierer N, Knight R (2010) Delivery mode shapes the acquisition and structure of the initial microbiota across multiple body habitats in newborns. Proc Natl Acad Sci USA 107:1197111975. https://doi.org/10.1073/pnas.1002601107

11. O'Toole PW, Claesson MJ (2010) Gut microbiota: changes throughout the lifespan from infancy to elderly. Int Dairy J 20:281-291. https://doi.org/10.1016/j.idairyj.2009.11.010
12. Das B, Ghosh TS, Kedia S, Rampal R, Saxena S, Bag S, Mitra R, Dayal M, Mehta O, Surendranath A, Travis SPL, Tripathi P, Nair GB, Ahuja V (2018) Analysis of the gut microbiome of rural and urban healthy indians living in sea level and high altitude areas. Sci Rep 8:10104. https://doi.org/10.1038/ s41598-018-28550-3

13. Priya S, Blekhman R (2019) Population dynamics of the human gut microbiome: change is the only constant. Genome Biol 20:150. https://doi.org/10.1186/s13059-019-1775-3

14. Medawar PB (1952) An unsolved problem of biology. Published for the college by $\mathrm{H}$. K, Lewis, London

15. López-Otín C, Blasco MA, Partridge L, Serrano M, Kroemer G (2013) The hallmarks of aging. Cell 153:1194-1217. https://doi. org/10.1016/j.cell.2013.05.039

16. Gems D, Partridge L (2013) Genetics of longevity in model organisms: debates and paradigm shifts. Annu Rev Physiol 75:621-644. https://doi.org/10.1146/annurev-physiol-030212-183712

17. Report HoL (2021) Ageing: Science, Technology and Healthy Living. UK. https://publications.parliament.uk/pa/ld5801/ldselect/ldsctech/ 183/183.pdf. Accessed 25 Dec 2021

18. Borghesan M, Hoogaars WMH, Varela-Eirin M, Talma N, Demaria M (2020) A senescence-centric view of aging: implications for longevity and disease. Trends Cell Biol 30:777-791. https://doi.org/10. 1016/j.tcb.2020.07.002

19. Burd CE, Sorrentino JA, Clark KS, Darr DB, Krishnamurthy J, Deal AM, Bardeesy N, Castrillon DH, Beach DH, Sharpless NE (2013) Monitoring tumorigenesis and senescence in vivo with a p16(INK4a)-luciferase model. Cell 152:340-351. https://doi.org/ 10.1016/j.cell.2012.12.010

20. Tuttle CSL, Luesken SWM, Waaijer MEC, Maier AB (2021) Senescence in tissue samples of humans with age-related diseases: a systematic review. Ageing Res Rev 68:101334. https:// doi.org/10.1016/j.arr.2021.101334

21. Herbig U, Ferreira M, Condel L, Carey D, Sedivy JM (2006) Cellular senescence in aging primates. Science 311:1257. https:// doi.org/10.1126/science.1122446

22. Baker DJ, Childs BG, Durik M, Wijers ME, Sieben CJ, Zhong J, Saltness RA, Jeganathan KB, Verzosa GC, Pezeshki A, Khazaie K, Miller JD, van Deursen JM (2016) Naturally occurring p16(Ink4a)-positive cells shorten healthy lifespan. Nature 530:184-189. https://doi.org/10.1038/nature16932

23. Gasek NS, Kuchel GA, Kirkland JL, Xu M (2021) Strategies for targeting senescent cells in human disease. Nat Aging 1:870879. https://doi.org/10.1038/s43587-021-00121-8

24. Baker DJ, Wijshake T, Tchkonia T, LeBrasseur NK, Childs BG, van de Sluis B, Kirkland JL, van Deursen JM (2011) Clearance of p16Ink4a-positive senescent cells delays ageingassociated disorders. Nature 479:232-236. https://doi.org/10. 1038/nature 10600

25. Zhu Y, Tchkonia T, Pirtskhalava T, Gower AC, Ding H, Giorgadze N, Palmer AK, Ikeno Y, Hubbard GB, Lenburg M, O'Hara SP, LaRusso NF, Miller JD, Roos CM, Verzosa GC, LeBrasseur NK, Wren JD, Farr JN, Khosla S, Stout MB, McGowan SJ, FuhrmannStroissnigg H, Gurkar AU, Zhao J, Colangelo D, Dorronsoro A, Ling YY, Barghouthy AS, Navarro DC, Sano T, Robbins PD, Niedernhofer LJ, Kirkland JL (2015) The achilles' heel of senescent cells: from transcriptome to senolytic drugs. Aging Cell 14:644-658. https://doi.org/10.1111/acel.12344

26. Salekeen R, Barua J, Shaha PR, Islam KMD, Islam ME, Billah MM, Rahman SMM (2021) Marine phycocompound screening reveals a potential source of novel senotherapeutics. J Biomol Struct Dyn. https://doi.org/10.1080/07391102.2021.1877822

27. Kirkland JL, Tchkonia T (2020) Senolytic drugs: from discovery to translation. J Intern Med 288:518-536. https://doi.org/10. 1111/joim.13141 
28. Hickson LJ, Langhi Prata LGP, Bobart SA, Evans TK, Giorgadze N, Hashmi SK, Herrmann SM, Jensen MD, Jia Q, Jordan KL, Kellogg TA, Khosla S, Koerber DM, Lagnado AB, Lawson DK, LeBrasseur NK, Lerman LO, McDonald KM, McKenzie TJ, Passos JF, Pignolo RJ, Pirtskhalava T, Saadiq IM, Schaefer KK, Textor SC, Victorelli SG, Volkman TL, Xue A, Wentworth MA, Wissler Gerdes EO, Zhu Y, Tchkonia T, Kirkland JL (2019) Senolytics decrease senescent cells in humans: preliminary report from a clinical trial of dasatinib plus quercetin in individuals with diabetic kidney disease. EBioMedicine 47:446-456. https://doi.org/10.1016/j.ebiom.2019.08.069

29. Dolgin E (2020) Send in the senolytics. Nat Biotechnol 38:13711377. https://doi.org/10.1038/s41587-020-00750-1

30. Justice JN, Nambiar AM, Tchkonia T, LeBrasseur NK, Pascual R, Hashmi SK, Prata L, Masternak MM, Kritchevsky SB, Musi N, Kirkland JL (2019) Senolytics in idiopathic pulmonary fibrosis: Results from a first-in-human, open-label, pilot study. EBioMedicine 40:554-563. https://doi.org/10.1016/j.ebiom.2018.12.052

31. Kim M, Benayoun BA (2020) The microbiome: an emerging key player in aging and longevity. Transl Med Aging 4:103-116. https://doi.org/10.1016/j.tma.2020.07.004

32. Mariat D, Firmesse O, Levenez F, Guimarăes VD, Sokol H, Doré J, Corthier G, Furet JP (2009) The Firmicutes/Bacteroidetes ratio of the human microbiota changes with age. BMC Microbiol 9:123. https://doi.org/10.1186/1471-2180-9-123

33. Hopkins MJ, Macfarlane GT (2002) Changes in predominant bacterial populations in human faeces with age and with Clostridium difficile infection. J Med Microbiol 51:448-454. https://doi.org/10.1099/0022-1317-51-5-448

34. Kong F, Hua Y, Zeng B, Ning R, Li Y, Zhao J (2016) Gut microbiota signatures of longevity. Curr Biol 26:R832-r833. https:// doi.org/10.1016/j.cub.2016.08.015

35. Claesson MJ, Cusack S, Sullivan O, Greene-Diniz R, de Weerd H, Flannery E, Marchesi JR, Falush D, Dinan T, Fitzgerald G, Stanton C, van Sinderen D, Connor M, Harnedy N, Connor K, Henry C, Mahony D, Fitzgerald AP, Shanahan F, Twomey C, Hill C, Ross RP, Toole PW (2011) Composition, variability, and temporal stability of the intestinal microbiota of the elderly. Proc Natl Acad Sci USA 108:4586. https://doi.org/10.1073/pnas. 1000097107

36. Ruiz-Ruiz S, Sanchez-Carrillo S, Ciordia S, Mena MC, Méndez-García C, Rojo D, Bargiela R, Zubeldia-Varela E, Martínez-Martínez M, Barbas C, Ferrer M, Moya A (2020) Functional microbiome deficits associated with ageing: chronological age threshold. Aging Cell 19:e13063. https://doi.org/10.1111/acel.13063

37. Herranz N, Gil J (2018) Mechanisms and functions of cellular senescence. J Clin Investig 128:1238-1246. https://doi.org/10. $1172 / \mathrm{JCI} 95148$

38. van Deursen JM (2014) The role of senescent cells in ageing. Nature 509:439-446. https://doi.org/10.1038/nature13193

39. Krishnamurthy J, Torrice C, Ramsey MR, Kovalev GI, AlRegaiey K, Su L, Sharpless NE (2004) Ink4a/Arf expression is a biomarker of aging. J Clin Invest 114:1299-1307. https://doi. org/10.1172/jci22475

40. Demaria M, Ohtani N, Youssef SA, Rodier F, Toussaint W, Mitchell JR, Laberge RM, Vijg J, Van Steeg H, Dollé ME, Hoeijmakers JH, de Bruin A, Hara E, Campisi J (2014) An essential role for senescent cells in optimal wound healing through secretion of PDGF-AA. Dev Cell 31:722-733. https://doi.org/10.1016/j.devcel.2014.11.012

41. Muñoz-Espín D, Cañamero M, Maraver A, Gómez-López G, Contreras J, Murillo-Cuesta S, Rodríguez-Baeza A, Varela-Nieto I, Ruberte J, Collado M, Serrano M (2013) Programmed cell senescence during mammalian embryonic development. Cell 155:1104-1118. https://doi.org/10.1016/j.cell.2013.10.019

42. He S, Sharpless NE (2017) Senescence in health and disease. Cell 169:1000-1011. https://doi.org/10.1016/j.cell.2017.05.015
43. Sager R (1991) Senescence as a mode of tumor suppression. Environ Health Perspect 93:59-62. https://doi.org/10.1289/ehp. 919359

44. Spallarossa P, Altieri P, Aloi C, Garibaldi S, Barisione C, Ghigliotti G, Fugazza G, Barsotti A, Brunelli C (2009) Doxorubicin induces senescence or apoptosis in rat neonatal cardiomyocytes by regulating the expression levels of the telomere binding factors 1 and 2 . Am J Physiol Heart Circ Physiol 297:H2169-2181. https://doi.org/ 10.1152/ajpheart.00068.2009

45. Childs BG, Baker DJ, Kirkland JL, Campisi J, van Deursen JM (2014) Senescence and apoptosis: dueling or complementary cell fates? EMBO Rep 15:1139-1153. https://doi.org/10.15252/embr. 201439245

46. Song P, An J, Zou M-H (2020) Immune clearance of senescent cells to combat ageing and chronic diseases. Cells 9:671. https:// doi.org/10.3390/cells9030671

47. Idda ML, McClusky WG, Lodde V, Munk R, Abdelmohsen K, Rossi M, Gorospe M (2020) Survey of senescent cell markers with age in human tissues. Aging 12:4052-4066. https://doi.org/ 10.18632/aging. 102903

48. Tuttle CSL, Waaijer MEC, Slee-Valentijn MS, Stijnen T, Westendorp R, Maier AB (2020) Cellular senescence and chronological age in various human tissues: A systematic review and meta-analysis. Aging Cell 19:e13083. https://doi.org/10.1111/acel.13083

49. Nelson G, Wordsworth J, Wang C, Jurk D, Lawless C, MartinRuiz C, von Zglinicki T (2012) A senescent cell bystander effect: senescence-induced senescence. Aging Cell 11:345-349. https:// doi.org/10.1111/j.1474-9726.2012.00795.x

50. Campisi J (2005) Senescent cells, tumor suppression, and organismal aging: good citizens, bad neighbors. Cell 120:513-522. https://doi.org/10.1016/j.cell.2005.02.003

51. Xu M, Bradley EW, Weivoda MM, Hwang SM, Pirtskhalava T, Decklever T, Curran GL, Ogrodnik M, Jurk D, Johnson KO, Lowe V, Tchkonia T, Westendorf JJ, Kirkland JL (2017) Transplanted senescent cells induce an osteoarthritis-like condition in mice. J Gerontol A Biol Sci Med Sci 72:780-785. https://doi.org/ 10.1093/gerona/glw154

52. Kim SR, Jiang K, Ferguson CM, Tang H, Chen X, Zhu X, Hickson LJ, Tchkonia T, Kirkland JL, Lerman LO (2020) Transplanted senescent renal scattered tubular-like cells induce injury in the mouse kidney. Am J Physiol Renal Physiol 318:F1167-F1176. https://doi.org/10.1152/ajprenal.00535.2019

53. Xu M, Pirtskhalava T, Farr JN, Weigand BM, Palmer AK, Weivoda MM, Inman CL, Ogrodnik MB, Hachfeld CM, Fraser DG, Onken JL, Johnson KO, Verzosa GC, Langhi LGP, Weigl M, Giorgadze N, LeBrasseur NK, Miller JD, Jurk D, Singh RJ, Allison DB, Ejima K, Hubbard GB, Ikeno Y, Cubro H, Garovic VD, Hou X, Weroha SJ, Robbins PD, Niedernhofer LJ, Khosla S, Tchkonia T, Kirkland JL (2018) Senolytics improve physical function and increase lifespan in old age. Nat Med 24:12461256. https://doi.org/10.1038/s41591-018-0092-9

54. Cai Y, Zhou H, Zhu Y, Sun Q, Ji Y, Xue A, Wang Y, Chen W, Yu X, Wang L, Chen H, Li C, Luo T, Deng H (2020) Elimination of senescent cells by $\beta$-galactosidase-targeted prodrug attenuates inflammation and restores physical function in aged mice. Cell Res 30:574-589. https://doi.org/10.1038/s41422-020-0314-9

55. de Magalhães JP, Passos JF (2018) Stress, cell senescence and organismal ageing. Mech Ageing Dev 170:2-9. https://doi.org/ 10.1016/j.mad.2017.07.001

56. Chen K, Shen W, Zhang Z, Xiong F, Ouyang Q, Luo C (2020) Age-dependent decline in stress response capacity revealed by proteins dynamics analysis. Sci Rep 10:15211. https://doi.org/ 10.1038/s41598-020-72167-4

57. Bulua AC, Simon A, Maddipati R, Pelletier M, Park H, Kim KY, Sack MN, Kastner DL, Siegel RM (2011) Mitochondrial 
reactive oxygen species promote production of proinflammatory cytokines and are elevated in TNFR1-associated periodic syndrome (TRAPS). J Exp Med 208:519-533. https://doi.org/10. 1084/jem.20102049

58. Campisi J (1997) The biology of replicative senescence. Eur J Cancer 33:703-709. https://doi.org/10.1016/s0959-8049(96)00058-5

59. Epel ES, Blackburn EH, Lin J, Dhabhar FS, Adler NE, Morrow JD, Cawthon RM (2004) Accelerated telomere shortening in response to life stress. Proc Natl Acad Sci USA 101:17312-17315. https:// doi.org/10.1073/pnas.0407162101

60. Tchirkov A, Lansdorp PM (2003) Role of oxidative stress in telomere shortening in cultured fibroblasts from normal individuals and patients with ataxia-telangiectasia. Hum Mol Genet 12:227-232. https://doi.org/10.1093/hmg/ddg023

61. Liu Y, Sanoff HK, Cho H, Burd CE, Torrice C, Ibrahim JG, Thomas NE, Sharpless NE (2009) Expression of p16(INK4a) in peripheral blood T-cells is a biomarker of human aging. Aging Cell 8:439448. https://doi.org/10.1111/j.1474-9726.2009.00489.x

62. Ovadya Y, Landsberger T, Leins H, Vadai E, Gal H, Biran A, Yosef R, Sagiv A, Agrawal A, Shapira A, Windheim J, Tsoory M, Schirmbeck R, Amit I, Geiger H, Krizhanovsky V (2018) Impaired immune surveillance accelerates accumulation of senescent cells and aging. Nat Commun 9:5435. https://doi.org/ 10.1038/s41467-018-07825-3

63. Burton DGA, Stolzing A (2018) Cellular senescence: immunosurveillance and future immunotherapy. Ageing Res Rev 43:1725. https://doi.org/10.1016/j.arr.2018.02.001

64. Yousefzadeh MJ, Flores RR, Zhu Y, Schmiechen ZC, Brooks RW, Trussoni CE, Cui Y, Angelini L, Lee K-A, McGowan SJ, Burrack AL, Wang D, Dong Q, Lu A, Sano T, O'Kelly RD, McGuckian CA, Kato JI, Bank MP, Wade EA, Pillai SPS, Klug J, Ladiges WC, Burd CE, Lewis SE, LaRusso NF, Vo NV, Wang Y, Kelley EE, Huard J, Stromnes IM, Robbins PD, Niedernhofer LJ (2021) An aged immune system drives senescence and ageing of solid organs. Nature. https://doi.org/10.1038/s41586-021-03547-7

65. Sharma R (2021) Perspectives on the dynamic implications of cellular senescence and immunosenescence on macrophage aging biology. Biogerontology 22:571-587. https://doi.org/10. 1007/s10522-021-09936-9

66. Pereira BI, Devine OP, Vukmanovic-Stejic M, Chambers ES, Subramanian P, Patel N, Virasami A, Sebire NJ, Kinsler V, Valdovinos A, LeSaux CJ, Passos JF, Antoniou A, Rustin MHA, Campisi J, Akbar AN (2019) Senescent cells evade immune clearance via HLA-E-mediated NK and CD8+ T cell inhibition. Nat Commun 10:2387. https://doi.org/10.1038/ s41467-019-10335-5

67. Sharma R (2021) Bioactive food components for managing cellular senescence in aging and disease: a critical appraisal and perspectives. PharmaNutrition 18:100281. https://doi.org/10. 1016/j.phanu.2021.100281

68. Zhang X, Yang Y, Su J, Zheng X, Wang C, Chen S, Liu J, Lv Y, Fan S, Zhao A, Chen T, Jia W, Wang X (2020) Age-related compositional changes and correlations of gut microbiome, serum metabolome, and immune factor in rats. GeroScience. https:// doi.org/10.1007/s11357-020-00188-y

69. Bana B, Cabreiro F (2019) The microbiome and aging. Annual Rev Genet 53:239-261. https://doi.org/10.1146/annur ev-genet-112618-043650

70. DeGruttola AK, Low D, Mizoguchi A, Mizoguchi E (2016) Current understanding of dysbiosis in disease in human and animal models. Inflamm Bowel Dis 22:1137-1150. https://doi.org/10. 1097/MIB.0000000000000750

71. Vaiserman A, Romanenko M, Piven L, Moseiko V, Lushchak O, Kryzhanovska N, Guryanov V, Koliada A (2020) Differences in the gut Firmicutes to Bacteroidetes ratio across age groups in healthy Ukrainian population. BMC Microbiol 20:221-221. https://doi.org/10.1186/s12866-020-01903-7

72. Salazar N, Valdés-Varela L, González S, Gueimonde M, de Los Reyes-Gavilán CG (2017) Nutrition and the gut microbiome in the elderly. Gut Microbes 8:82-97. https://doi.org/10.1080/ 19490976.2016.1256525

73. Kamo T, Akazawa H, Suda W, Saga-Kamo A, Shimizu Y, Yagi H, Liu Q, Nomura S, Naito AT, Takeda N, Harada M, Toko H, Kumagai H, Ikeda Y, Takimoto E, Suzuki JI, Honda K, Morita H, Hattori M, Komuro I (2017) Dysbiosis and compositional alterations with aging in the gut microbiota of patients with heart failure. PLoS One 12:e174099. https://doi.org/10.1371/journal. pone.0174099

74. Lee HJ, Lee KE, Kim JK, Kim DH (2019) Suppression of gut dysbiosis by Bifidobacterium longum alleviates cognitive decline in 5XFAD transgenic and aged mice. Sci Rep 9:11814. https:// doi.org/10.1038/s41598-019-48342-7

75. Cardenas K, Dao V, Hurez V, Curiel T (2014) Age-related gut dysbiosis contributes to age-related colitis and colon cancer risk and appears B7-H1-dependent. (HUM8P.352). J Immunol 192(185): 27

76. Wilmanski T, Diener C, Rappaport N, Patwardhan S, Wiedrick J, Lapidus J, Earls JC, Zimmer A, Glusman G, Robinson M, Yurkovich JT, Kado DM, Cauley JA, Zmuda J, Lane NE, Magis AT, Lovejoy JC, Hood L, Gibbons SM, Orwoll ES, Price ND (2021) Gut microbiome pattern reflects healthy ageing and predicts survival in humans. Nat Metab 3:274-286. https://doi.org/ 10.1038/s42255-021-00348-0

77. Galkin F, Mamoshina P, Aliper A, Putin E, Moskalev V, Gladyshev VN, Zhavoronkov A (2020) Human gut microbiome aging clock based on taxonomic profiling and deep learning. iScience 23:101199. https:// doi.org/10.1016/j.isci.2020.101199

78. Elliott ML, Caspi A, Houts RM, Ambler A, Broadbent JM, Hancox RJ, Harrington H, Hogan S, Keenan R, Knodt A, Leung JH, Melzer TR, Purdy SC, Ramrakha S, Richmond-Rakerd LS, Righarts A, Sugden K, Thomson WM, Thorne PR, Williams BS, Wilson G, Hariri AR, Poulton R, Moffitt TE (2021) Disparities in the pace of biological aging among midlife adults of the same chronological age have implications for future frailty risk and policy. Nat Aging 1:295-308. https://doi.org/10.1038/s43587-021-00044-4

79. Wu JW, Yaqub A, Ma Y, Koudstaal W, Hofman A, Ikram MA, Ghanbari M, Goudsmit J (2021) Biological age in healthy elderly predicts aging-related diseases including dementia. Sci Rep 11:15929. https://doi.org/10.1038/s41598-021-95425-5

80. Maffei VJ, Kim S, Et B, Luo M, Jazwinski SM, Taylor CM, Welsh DA (2017) Biological aging and the human gut microbiota. J Gerontol A Biol Sci Med Sci 72:1474-1482. https://doi. org/10.1093/gerona/glx042

81. Ke S, Mitchell SJ, MacArthur MR, Kane AE, Sinclair DA, Venable EM, Chadaideh KS, Carmody RN, Grodstein F, Mitchell JR, Liu Y (2021) Gut microbiota predicts healthy late-life aging in male mice. Nutrients 13:3290

82. Iatsenko I, Boquete JP, Lemaitre B (2018) Microbiota-derived lactate activates production of reactive oxygen species by the intestinal nadph oxidase nox and shortens Drosophila lifespan. Immunity 49:929-942.e5. https://doi.org/10.1016/j.immuni.2018. 09.017

83. Smith P, Willemsen D, Popkes M, Metge F, Gandiwa E, Reichard M, Valenzano DR (2017) Regulation of life span by the gut microbiota in the short-lived African turquoise killifish. Elife 6:e27014. https://doi.org/10.7554/eLife.27014

84. Fransen F, van Beek AA, Borghuis T, Aidy SE, Hugenholtz F, van der Gaast - de Jongh C, Savelkoul HFJ, De Jonge MI, Boekschoten MV, Smidt H, Faas MM, de Vos P (2017) Aged gut microbiota contributes to systemical inflammaging after transfer to germ-free 
mice. Front Immunol 8:1385. https://doi.org/10.3389/fimmu.2017. 01385

85. D’Amato A, Di Cesare ML, Lucarini E, Man AL, Le Gall G, Branca JJV, Ghelardini C, Amedei A, Bertelli E, Regoli M, Pacini A, Luciani G, Gallina P, Altera A, Narbad A, Gulisano M, Hoyles L, Vauzour D, Nicoletti C (2020) Faecal microbiota transplant from aged donor mice affects spatial learning and memory via modulating hippocampal synaptic plasticity- and neurotransmission-related proteins in young recipients. Microbiome 8:140. https://doi.org/10.1186/s40168-020-00914-w

86. Lee J, Venna VR, Durgan DJ, Shi H, Hudobenko J, Putluri N, Petrosino J, McCullough LD, Bryan RM (2020) Young versus aged microbiota transplants to germ-free mice: increased short-chain fatty acids and improved cognitive performance. Gut Microbes 12:1-14. https://doi. org/10.1080/19490976.2020.1814107

87. Li Y, Ning L, Yin Y, Wang R, Zhang Z, Hao L, Wang B, Zhao X, Yang X, Yin L, Wu S, Guo D, Zhang C (2020) Age-related shifts in gut microbiota contribute to cognitive decline in aged rats. Aging (Albany NY) 12:7801-7817. https://doi.org/10.18632/ aging. 103093

88. Jørgensen SMD, Rubak TMM, Damsgaard EM, Dahlerup JF, Hvas CL (2020) Faecal microbiota transplantation as a home therapy to frail older people. Age Ageing 49:1093-1096. https:// doi.org/10.1093/ageing/afaa073

89. Kundu P, Lee HU, Garcia-Perez I, Tay EXY, Kim H, Faylon LE, Martin KA, Purbojati R, Drautz-Moses DI, Ghosh S, Nicholson JK, Schuster S, Holmes E, Pettersson S (2019) Neurogenesis and prolongevity signaling in young germ-free mice transplanted with the gut microbiota of old mice. Sci Transl Med 11:4760. https://doi.org/10.1126/scitranslmed.aau4760

90. Anand R, Song Y, Garg S, Girotra M, Sinha A, Sivaraman A, Phillips L, Dutta SK (2017) Effect of aging on the composition of fecal microbiota in donors for FMT and its impact on clinical outcomes. Dig Dis Sci 62:1002-1008. https://doi.org/10.1007/ s10620-017-4449-6

91. Elderman M, Sovran B, Hugenholtz F, Graversen K, Huijskes M, Houtsma E, Belzer C, Boekschoten M, de Vos P, Dekker J, Wells J, Faas M (2017) The effect of age on the intestinal mucus thickness, microbiota composition and immunity in relation to sex in mice. PLoS One 12:e184274-e0184274. https://doi.org/ 10.1371/journal.pone.0184274

92. Tran L, Greenwood-Van Meerveld B (2013) Age-associated remodeling of the intestinal epithelial barrier. J Gerontol A Biol Sci Med Sci 68:1045-1056. https://doi.org/10.1093/gerona/glt106

93. Thevaranjan N, Puchta A, Schulz C, Naidoo A, Szamosi JC, Verschoor CP, Loukov D, Schenck LP, Jury J, Foley KP, Schertzer JD, Larché MJ, Davidson DJ, Verdú EF, Surette MG, Bowdish DME (2017) Age-associated microbial dysbiosis promotes intestinal permeability, systemic inflammation, and macrophage dysfunction. Cell Host Microbe 21:455-466.e4. https://doi.org/10.1016/j.chom.2017.03.002

94. Choi J, Hur TY, Hong Y (2018) Influence of altered gut microbiota composition on aging and aging-related diseases. J Lifestyle Med 8:1-7. https://doi.org/10.15280/jlm.2018.8.1.1

95. Haran JP, McCormick BA (2021) Aging, frailty, and the microbiome-how dysbiosis influences human aging and disease. Gastroenterology 160:507-523. https://doi.org/10.1053/j. gastro.2020.09.060

96. Gurung M, Li Z, You H, Rodrigues R, Jump DB, Morgun A, Shulzhenko N (2020) Role of gut microbiota in type 2 diabetes pathophysiology. EBioMedicine 51:102590-102590. https://doi. org/10.1016/j.ebiom.2019.11.051

97. Doumatey AP, Adeyemo A, Zhou J, Lei L, Adebamowo SN, Adebamowo C, Rotimi CN (2020) Gut microbiome profiles are associated with type 2 diabetes in urban africans. Front Cell Infect Microbiol 10:63. https://doi.org/10.3389/fcimb.2020.00063
98. Das T, Jayasudha R, Chakravarthy S, Prashanthi GS, Bhargava A, Tyagi M, Rani PK, Pappuru RR, Sharma S, Shivaji S (2021) Alterations in the gut bacterial microbiome in people with type 2 diabetes mellitus and diabetic retinopathy. Sci Rep 11:2738. https://doi.org/10.1038/s41598-021-82538-0

99. Almugadam BS, Liu Y, Chen SM, Wang CH, Shao CY, Ren BW, Tang L (2020) Alterations of gut microbiota in type 2 diabetes individuals and the confounding effect of antidiabetic agents. J Diabetes Res 2020:7253978. https://doi.org/10.1155/2020/7253978

100. Poore GD, Kopylova E, Zhu Q, Carpenter C, Fraraccio S, Wandro S, Kosciolek T, Janssen S, Metcalf J, Song SJ, Kanbar J, MillerMontgomery S, Heaton R, McKay R, Patel SP, Swafford AD, Knight R (2020) Microbiome analyses of blood and tissues suggest cancer diagnostic approach. Nature 579:567-574. https://doi.org/10.1038/ s41586-020-2095-1

101. Zhuang H, Cheng L, Wang Y, Zhang YK, Zhao MF, Liang GD, Zhang MC, Li YG, Zhao JB, Gao YN, Zhou YJ, Liu SL (2019) Dysbiosis of the gut microbiome in lung cancer. Front Cell Infect Microbiol 9:112. https://doi.org/10.3389/fcimb.2019.00112

102. Nakatsu G, Li X, Zhou H, Sheng J, Wong SH, Wu WK, Ng SC, Tsoi H, Dong Y, Zhang N, He Y, Kang Q, Cao L, Wang K, Zhang J, Liang Q, Yu J, Sung JJ (2015) Gut mucosal microbiome across stages of colorectal carcinogenesis. Nat Commun 6:8727. https:// doi.org/10.1038/ncomms9727

103. Ferreira RM, Pereira-Marques J, Pinto-Ribeiro I, Costa JL, Carneiro F, Machado JC, Figueiredo C (2018) Gastric microbial community profiling reveals a dysbiotic cancer-associated microbiota. Gut 67:226. https://doi.org/10.1136/gutjnl-2017-314205

104. Half E, Keren N, Reshef L, Dorfman T, Lachter I, Kluger Y, Reshef N, Knobler H, Maor Y, Stein A, Konikoff FM, Gophna U (2019) Fecal microbiome signatures of pancreatic cancer patients. Sci Rep 9:16801. https://doi.org/10.1038/ s41598-019-53041-4

105. Daisley BA, Chanyi RM, Abdur-Rashid K, Al KF, Gibbons S, Chmiel JA, Wilcox H, Reid G, Anderson A, Dewar M, Nair SM, Chin J, Burton JP (2020) Abiraterone acetate preferentially enriches for the gut commensal Akkermansia muciniphila in castrate-resistant prostate cancer patients. Nat Commun 11:4822. https://doi.org/10.1038/s41467-020-18649-5

106. Goedert JJ, Jones G, Hua X, Xu X, Yu G, Flores R, Falk RT, Gail MH, Shi J, Ravel J, Feigelson HS (2015) Investigation of the association between the fecal microbiota and breast cancer in postmenopausal women: a population-based case-control pilot study. J Natl Cancer Inst 107(8):djv147. https://doi.org/10.1093/ jnci/djv147

107. D'Alessandro G, Antonangeli F, Marrocco F, Porzia A, Lauro C, Santoni A, Limatola C (2020) Gut microbiota alterations affect glioma growth and innate immune cells involved in tumor immunosurveillance in mice. Eur J Immunol 50:705-711. https://doi. org/10.1002/eji.201948354

108. Vicente-Dueñas C, Janssen S, Oldenburg M, Auer F, González-Herrero I, Casado-García A, Isidro-Hernández M, Raboso-Gallego J, Westhoff P, Pandyra AA, Hein D, Gössling KL, Alonso-López D, De Las RJ, Bhatia S, GarcíaCriado FJ, García-Cenador MB, Weber APM, Köhrer K, Hauer J, Fischer U, Sánchez-García I, Borkhardt A (2020) An intact gut microbiome protects genetically predisposed mice against leukemia. Blood 136:2003-2017. https://doi.org/ 10.1182/blood.2019004381

109. Parida S, Sharma D (2021) The microbiome and cancer: creating friendly neighborhoods and removing the foes within. Cancer Res 81:790. https://doi.org/10.1158/0008-5472.CAN-20-2629

110. Jie Z, Xia H, Zhong SL, Feng Q, Li S, Liang S, Zhong H, Liu Z, Gao Y, Zhao H, Zhang D, Su Z, Fang Z, Lan Z, Li J, Xiao L, Li J, Li R, Li X, Li F, Ren H, Huang Y, Peng Y, Li G, Wen B, Dong B, 
Chen JY, Geng QS, Zhang ZW, Yang H, Wang J, Wang J, Zhang X, Madsen L, Brix S, Ning G, Xu X, Liu X, Hou Y, Jia H, He K, Kristiansen K (2017) The gut microbiome in atherosclerotic cardiovascular disease. Nat Commun 8:845. https://doi.org/10. 1038/s41467-017-00900-1

111. Zhu Q, Gao R, Zhang Y, Pan D, Zhu Y, Zhang X, Yang R, Jiang $\mathrm{R}, \mathrm{Xu}$ Y, Qin H (2018) Dysbiosis signatures of gut microbiota in coronary artery disease. Physiol Genomics 50:893-903. https:// doi.org/10.1152/physiolgenomics.00070.2018

112. Karlsson FH, Fåk F, Nookaew I, Tremaroli V, Fagerberg B, Petranovic D, Bäckhed F, Nielsen J (2012) Symptomatic atherosclerosis is associated with an altered gut metagenome. Nat Commun 3:1245. https://doi.org/10.1038/ncomms2266

113. Luedde M, Winkler T, Heinsen FA, Rühlemann MC, Spehlmann ME, Bajrovic A, Lieb W, Franke A, Ott SJ, Frey N (2017) Heart failure is associated with depletion of core intestinal microbiota. ESC Heart Fail 4:282-290. https://doi.org/10.1002/ehf2.12155

114. Cui X, Ye L, Li J, Jin L, Wang W, Li S, Bao M, Wu S, Li L, Geng B, Zhou X, Zhang J, Cai J (2018) Metagenomic and metabolomic analyses unveil dysbiosis of gut microbiota in chronic heart failure patients. Sci Rep 8:635. https://doi.org/10.1038/ s41598-017-18756-2

115. Tang WHW, Wang Z, Fan Y, Levison B, Hazen JE, Donahue LM, Wu Y, Hazen SL (2014) Prognostic value of elevated levels of intestinal microbe-generated metabolite trimethylamine-N-oxide in patients with heart failure: refining the gut hypothesis. J Am Coll Cardiol 64:1908-1914. https://doi.org/10.1016/j.jacc.2014.02.617

116. Wang Z, Klipfell E, Bennett BJ, Koeth R, Levison BS, Dugar B, Feldstein AE, Britt EB, Fu X, Chung YM, Wu Y, Schauer P, Smith JD, Allayee H, Tang WH, DiDonato JA, Lusis AJ, Hazen SL (2011) Gut flora metabolism of phosphatidylcholine promotes cardiovascular disease. Nature 472:57-63. https://doi.org/10. 1038/nature09922

117. Holmes E, Li JV, Marchesi JR, Nicholson JK (2012) Gut microbiota composition and activity in relation to host metabolic phenotype and disease risk. Cell Metab 16:559-564. https://doi.org/ 10.1016/j.cmet.2012.10.007

118. Conway J, Niharika AD (2021) Ageing of the gut microbiome: potential influences on immune senescence and inflammageing. Ageing Res Rev 68:101323. https://doi.org/10.1016/j.arr.2021. 101323

119. Buford TW (2017) (Dis)Trust your gut: the gut microbiome in age-related inflammation, health, and disease. Microbiome 5:80. https://doi.org/10.1186/s40168-017-0296-0

120. Aw D, Silva AB, Palmer DB (2007) Immunosenescence: emerging challenges for an ageing population. Immunology 120:435446. https://doi.org/10.1111/j.1365-2567.2007.02555.x

121. De la Fuente M, Miquel J (2009) An update of the oxidationinflammation theory of aging: the involvement of the immune system in oxi-inflamm-aging. Curr Pharm Des 15:3003-3026. https://doi.org/10.2174/138161209789058110

122. Song P, An J, Zou MH (2020) Immune clearance of senescent cells to combat ageing and chronic diseases. Cells 9(3):671. https://doi.org/10.3390/cells9030671

123. Zhang D, Chen G, Manwani D, Mortha A, Xu C, Faith JJ, Burk RD, Kunisaki Y, Jang JE, Scheiermann C, Merad M, Frenette PS (2015) Neutrophil ageing is regulated by the microbiome. Nature 525:528-532. https://doi.org/10.1038/nature15367

124. Renson A, Mullan Harris K, Dowd JB, Gaydosh L, McQueen MB, Krauter KS, Shannahan M, Aiello AE (2020) Early signs of gut microbiome aging: biomarkers of inflammation, metabolism, and macromolecular damage in young adulthood. J Gerontol A Biol Sci Med Sci 75:1258-1266. https://doi.org/10.1093/gerona/ glaa122

125. Shen X, Miao J, Wan Q, Wang S, Li M, Pu F, Wang G, Qian W, Yu Q, Marotta F, He F (2018) Possible correlation between gut microbiota and immunity among healthy middle-aged and elderly people in southwest China. Gut Pathog 10:4. https://doi.org/10. 1186/s13099-018-0231-3

126. Donaldson DS, Pollock J, Vohra P, Stevens MP, Mabbott NA (2020) Microbial stimulation reverses the age-related decline in $\mathrm{M}$ cells in aged mice. iScience 23:101147. https://doi.org/10. 1016/j.isci.2020.101147

127. Guigoz Y, Rochat F, Perruisseau-Carrier G, Rochat I, Schiffrin EJ (2002) Effects of oligosaccharide on the faecal flora and nonspecific immune system in elderly people. Nut Res 22:13-25. https://doi.org/10.1016/S0271-5317(01)00354-2

128. Sharma R, Kapila R, Dass G, Kapila S (2014) Improvement in Th1/Th2 immune homeostasis, antioxidative status and resistance to pathogenic E. coli on consumption of probiotic Lactobacillus rhamnosus fermented milk in aging mice. Age 36:9686. https://doi.org/10.1007/s11357-014-9686-4

129. Oliphant K, Allen-Vercoe E (2019) Macronutrient metabolism by the human gut microbiome: major fermentation by-products and their impact on host health. Microbiome 7:91. https://doi.org/10. 1186/s40168-019-0704-8

130. Colldén H, Landin A, Wallenius V, Elebring E, Fändriks L, Nilsson ME, Ryberg H, Poutanen M, Sjögren K, Vandenput $\mathrm{L}$, Ohlsson C (2019) The gut microbiota is a major regulator of androgen metabolism in intestinal contents. Am J Physiol Endocrinol Metab 317:E1182-E1192. https://doi.org/10.1152/ ajpendo.00338.2019

131. Agus A, Clément K, Sokol H (2021) Gut microbiota-derived metabolites as central regulators in metabolic disorders. Gut 70:1174. https://doi.org/10.1136/gutjnl-2020-323071

132. Clarke G, Stilling RM, Kennedy PJ, Stanton C, Cryan JF, Dinan TG (2014) Minireview: gut microbiota: the neglected endocrine organ. Mol Endocrinol (Baltimore, Md.) 28:1221-1238. https:// doi.org/10.1210/me.2014-1108

133. Colavitti R, Finkel T (2005) Reactive oxygen species as mediators of cellular senescence. IUBMB Life 57:277-281. https://doi. org/10.1080/15216540500091890

134. Zhang Y, Unnikrishnan A, Deepa SS, Liu Y, Li Y, Ikeno Y, Sosnowska D, Van Remmen H, Richardson A (2017) A new role for oxidative stress in aging: the accelerated aging phenotype in Sod1-/- mice is correlated to increased cellular senescence. Red Biol 11:30-37. https://doi.org/10.1016/j.redox.2016.10.014

135. Kumar R, Sharma A, Kumari A, Gulati A, Padwad Y, Sharma R (2019) Epigallocatechin gallate suppresses premature senescence of preadipocytes by inhibition of PI3K/Akt/mTOR pathway and induces senescent cell death by regulation of Bax/Bcl-2 pathway. Biogerontology 20:171-189. https://doi.org/10.1007/ s10522-018-9785-1

136. Varela-Eirín M, Carpintero-Fernández P, Sánchez-Temprano A, Varela-Vázquez A, Paíno CL, Casado-Díaz A, Continente AC, Mato V, Fonseca E, Kandouz M, Blanco A, Caeiro JR, Mayán MD (2020) Senolytic activity of small molecular polyphenols from olive restores chondrocyte redifferentiation and promotes a pro-regenerative environment in osteoarthritis. Aging 12:1588215905. https://doi.org/10.18632/aging.103801

137. Chang PV, Hao L, Offermanns S, Medzhitov R (2014) The microbial metabolite butyrate regulates intestinal macrophage function via histone deacetylase inhibition. Proc Natl Acad Sci USA 111:2247. https://doi.org/10.1073/pnas.1322269111

138. Wang LC, Pan TM, Tsai TY (2018) Lactic acid bacteria-fermented product of green tea and Houttuynia cordata leaves exerts antiadipogenic and anti-obesity effects. J Food Drug Anal 26:973-984. https://doi.org/10.1016/j.jfda.2017.11.009

139. Chung HJ, Lee H, Na G, Jung H, Kim DG, Shin SI, Jung SE, Choi ID, Lee JH, Sim JH, Choi HK (2020) Metabolic and lipidomic profiling of vegetable juices fermented with various probiotics. Biomolecules 10:725. https://doi.org/10.3390/biom10050725 
140. De Marco S, Sichetti M, Muradyan D, Piccioni M, Traina G, Pagiotti R, Pietrella D (2018) Probiotic cell-free supernatants exhibited anti-inflammatory and antioxidant activity on human gut epithelial cells and macrophages stimulated with lps. Evid Based Complement Alternat Med 2018:1756308. https://doi. org/10.1155/2018/1756308

141. Riaz Rajoka MS, Zhao H, Mehwish HM, Li N, Lu Y, Lian Z, Shao D, Jin M, Li Q, Zhao L, Shi J (2019) Anti-tumor potential of cell free culture supernatant of Lactobacillus rhamnosus strains isolated from human breast milk. Food Res Int 123:286-297. https://doi.org/10.1016/j.foodres.2019.05.002

142. Rossi T, Vergara D, Fanini F, Maffia M, Bravaccini S, Pirini F (2020) Microbiota-derived metabolites in tumor progression and metastasis. Int J Mol Sci 21:5786. https://doi.org/10.3390/ ijms21165786

143. Parkar SG, Trower TM, Stevenson DE (2013) Fecal microbial metabolism of polyphenols and its effects on human gut microbiota. Anaerobe 23:12-19. https://doi.org/10.1016/j.anaerobe. 2013.07.009

144. Sharma R, Padwad Y (2020) Plant-polyphenols based secondgeneration synbiotics: emerging concepts, challenges, and opportunities. Nutrition 77:110785. https://doi.org/10.1016/j. nut.2020.110785

145. Sharma R, Kumari M, Kumari A, Sharma A, Gulati A, Gupta M, Padwad Y (2019) Diet supplemented with phytochemical epigallocatechin gallate and probiotic Lactobacillus fermentum confers second generation synbiotic effects by modulating cellular immune responses and antioxidant capacity in aging mice. Eur J Nutr 58:2943-2957. https://doi.org/10.1007/ s00394-018-01890-6

146. Kumar R, Sharma A, Gupta M, Padwad Y, Sharma R (2020) Cell-free culture supernatant of probiotic Lactobacillus fermentum protects against $\mathrm{h}_{2} \mathrm{O}_{2}$-induced premature senescence by suppressing ros-akt-mtor axis in murine preadipocytes. Probiotics Antimicrob Proteins 12:563-576. https://doi.org/ 10.1007/s12602-019-09576-z

147. Gervason S, Napoli M, Dreux-Zhiga A, Lazzarelli C, Garcier S, Briand A, Albouy M, Thepot A, Berthon JY, Filaire E (2019) Attenuation of negative effects of senescence in human skin using an extract from Sphingomonas hydrophobicum: development of new skin care solution. Int J Cosmet Sci 41:391-397. https://doi.org/10.1111/ics.12534

148. Yousefzadeh MJ, Zhao J, Bukata C, Wade EA, McGowan SJ, Angelini LA, Bank MP, Gurkar AU, McGuckian CA, Calubag MF, Kato JI, Burd CE, Robbins PD, Niedernhofer LJ (2020) Tissue specificity of senescent cell accumulation during physiologic and accelerated aging of mice. Aging Cell 19:e13094. https://doi.org/10.1111/acel.13094

149. Sharma R, Kumar R, Sharma A, Goel A, Padwad Y (2021) Long term consumption of green tea EGCG enhances healthspan and lifespan in mice by mitigating multiple aspects of cellular senescence in mitotic and post-mitotic tissues, gut dysbiosis and immunosenescence. bioRxiv. https://doi.org/ 10.1101/2021.01.01.425058

150. Uchida R, Saito Y, Nogami K, Kajiyama Y, Suzuki Y, Kawase Y, Nakaoka T, Muramatsu T, Kimura M, Saito H (2018) Epigenetic silencing of Lgr5 induces senescence of intestinal epithelial organoids during the process of aging. npj Aging Mech Dis 4:12. https://doi.org/10.1038/s41514-018-0031-5

151. Moorefield EC, Andres SF, Blue RE, Van Landeghem L, Mah AT, Santoro MA, Ding S (2017) Aging effects on intestinal homeostasis associated with expansion and dysfunction of intestinal epithelial stem cells. Aging 9:1898-1915. https://doi.org/ 10.18632/aging. 101279

152. Kumar S, Suman S, Fornace AJ, Datta K (2019) Intestinal stem cells acquire premature senescence and senescence associated secretory phenotype concurrent with persistent DNA damage after heavy ion radiation in mice. Aging 11:4145-4158. https:// doi.org/10.18632/aging.102043

153. Yoshimoto S, Loo TM, Atarashi K, Kanda H, Sato S, Oyadomari $\mathrm{S}$, Iwakura Y, Oshima K, Morita H, Hattori M, Honda K, Ishikawa Y, Hara E, Ohtani N (2013) Obesity-induced gut microbial metabolite promotes liver cancer through senescence secretome. Nature 499:97-101. https://doi.org/10.1038/nature12347

154. Guo Y, Ayers JL, Carter KT, Wang T, Maden SK, Edmond D, Newcomb PP, Li C, Ulrich C, Yu M, Grady WM (2019) Senescence-associated tissue microenvironment promotes colon cancer formation through the secretory factor GDF15. Aging Cell 18:e13013. https://doi.org/10.1111/acel.13013

155. Chen Z, Trotman LC, Shaffer D, Lin HK, Dotan ZA, Niki M, Koutcher JA, Scher HI, Ludwig T, Gerald W, Cordon-Cardo C, Pandolfi PP (2005) Crucial role of p53-dependent cellular senescence in suppression of Pten-deficient tumorigenesis. Nature 436:725-730. https://doi.org/10.1038/nature03918

156. Thangaraju M, Cresci GA, Liu K, Ananth S, Gnanaprakasam JP, Browning DD, Mellinger JD, Smith SB, Digby GJ, Lambert NA, Prasad PD, Ganapathy V (2009) GPR109A is a G-protein-coupled receptor for the bacterial fermentation product butyrate and functions as a tumor suppressor in colon. Cancer Res 69:2826-2832. https://doi.org/10.1158/0008-5472.Can-08-4466

157. Wei W, Sun W, Yu S, Yang Y, Ai L (2016) Butyrate production from high-fiber diet protects against lymphoma tumor. Leuk Lymphoma 57:2401-2408. https://doi.org/10.3109/10428194.2016.1144879

158. Abrahamse SL, Pool-Zobel BL, Rechkemmer G (1999) Potential of short chain fatty acids to modulate the induction of DNA damage and changes in the intracellular calcium concentration by oxidative stress in isolated rat distal colon cells. Carcinogenesis 20:629-634. https://doi.org/10.1093/carcin/20.4.629

159. Ebert MN, Klinder A, Peters WH, Schäferhenrich A, Sendt W, Scheele J, Pool-Zobel BL (2003) Expression of glutathione S-transferases (GSTs) in human colon cells and inducibility of GSTM2 by butyrate. Carcinogenesis 24:1637-1644. https://doi. org/10.1093/carcin/bgg122

160. Sharma R, Padwad Y (2020) Nutraceuticals-based immunotherapeutic concepts and opportunities for the mitigation of cellular senescence and aging: a narrative review. Ageing Res Rev 63:101141. https://doi.org/10.1016/j.arr.2020.101141

161. Sharma R, Padwad Y (2020) Probiotic bacteria as modulators of cellular senescence: emerging concepts and opportunities. Gut Microbes 11:335-349. https://doi.org/10.1080/19490976.2019. 1697148

162. Sharma R, Padwad Y (2020) Perspectives of the potential implications of polyphenols in influencing the interrelationship between oxi-inflammatory stress, cellular senescence and immunosenescence during aging. Trends Food Sci Technol 98:41-52. https://doi.org/10.1016/j.tifs.2020.02.004

163. Saccon TD, Nagpal R, Yadav H, Cavalcante MB, Nunes ADdC, Schneider A, Gesing A, Hughes B, Yousefzadeh M, Tchkonia T, Kirkland JL, Niedernhofer LJ, Robbins PD, Masternak MM (2021) Senolytic combination of dasatinib and quercetin alleviates intestinal senescence and inflammation and modulates the gut microbiome in aged mice. J Gerontol A Biol Sci Med Sci. https://doi.org/10.1093/gerona/glab002

164. Zhang X, Zhu X, Sun Y, Hu B, Sun Y, Jabbar S, Zeng X (2013) Fermentation in vitro of EGCG, GCG and EGCG3"Me isolated from Oolong tea by human intestinal microbiota. Food Res Int 54:1589-1595. https://doi.org/10.1016/j.foodres.2013.10.005

165. Lin J, Nie X, Xiong Y, Gong Z, Chen J, Chen C, Huang Y, Liu $\mathrm{T}$ (2020) Fisetin regulates gut microbiota to decrease CCR9(+)/ CXCR3(+)/CD4(+) T-lymphocyte count and IL-12 secretion to alleviate premature ovarian failure in mice. Am J Transl Res 12:203-247 
166. Chen TJ, Feng Y, Liu T, Wu TT, Chen YJ, Li X, Li Q, Wu YC (2020) Fisetin regulates gut microbiota and exerts neuroprotective effect on mouse model of parkinson's disease. Front Neurosci. https://doi.org/10.3389/fnins.2020.549037

167. Shi T, Bian X, Yao Z, Wang Y, Gao W, Guo C (2020) Quercetin improves gut dysbiosis in antibiotic-treated mice. Food Funct 11:8003-8013. https://doi.org/10.1039/d0fo01439g

168. Lin R, Piao M, Song Y (2019) Dietary quercetin increases colonic microbial diversity and attenuates colitis severity in Citrobacter rodentium-infected mice. Front Microbiol 10:10921092. https://doi.org/10.3389/fmicb.2019.01092

169. Dos Santos AS, de Albuquerque TMR, de Brito Alves JL, de Souza EL (2019) Effects of quercetin and resveratrol on in vitro properties related to the functionality of potentially probiotic lactobacillus strains. Front Microbiol 10:2229-2229. https://doi.org/ 10.3389/fmicb.2019.02229

170. Jeong JJ, Kim KA, Jang SE, Woo J-Y, Han MJ, Kim DH (2015) Orally administrated Lactobacillus pentosus var. plantarum C29 ameliorates age-dependent colitis by inhibiting the nuclear factorkappa B signaling pathway via the regulation of lipopolysaccharide production by gut microbiota. PLoS One 10:e0116533-e0116533. https://doi.org/10.1371/journal.pone.0116533

171. Jeong JJ, Kim KA, Hwang YJ, Han MJ, Kim DH (2016) Antiinflammaging effects of Lactobacillus brevis OW38 in aged mice. Benef Microbes 7:707-718. https://doi.org/10.3920/ bm2016.0016

172. Jeong JJ, Woo JY, Ahn YT, Shim JH, Huh CS, Im SH, Han MJ, Kim DH (2015) The probiotic mixture IRT5 ameliorates age-dependent colitis in rats. Int Immunopharmacol 26:416-422. https://doi.org/10.1016/j.intimp.2015.04.021

173. Zierer J, Jackson MA, Kastenmüller G, Mangino M, Long T, Telenti A, Mohney RP, Small KS, Bell JT, Steves CJ, Valdes AM, Spector TD, Menni C (2018) The fecal metabolome as a functional readout of the gut microbiome. Nat Genet 50:790-795. https://doi.org/10.1038/s41588-018-0135-7

174. Frias-Lopez J, Shi Y, Tyson GW, Coleman ML, Schuster SC, Chisholm SW, Delong EF (2008) Microbial community gene expression in ocean surface waters. Proc Natl Acad Sci USA 105:3805-3810. https://doi.org/10.1073/pnas.0708897105

175. Vascellari S, Palmas V, Melis M, Pisanu S, Cusano R, Uva P, Perra D, Madau V, Sarchioto M, Oppo V, Simola N, Morelli M,
Santoru ML, Atzori L, Melis M, Cossu G, Manzin A (2020) Gut microbiota and metabolome alterations associated with parkinson's disease. mSystems 5:e00561-e620. https://doi.org/10.1128/ mSystems.00561-20

176. Tang Z-Z, Chen G, Hong Q, Huang S, Smith HM, Shah RD, Scholz M, Ferguson JF (2019) Multi-omic analysis of the microbiome and metabolome in healthy subjects reveals microbiomedependent relationships between diet and metabolites. Front Genet 10:454. https://doi.org/10.3389/fgene.2019.00454

177. Jain A, Li XH, Chen WN (2019) An untargeted fecal and urine metabolomics analysis of the interplay between the gut microbiome, diet and human metabolism in Indian and Chinese adults. Sci Rep 9:9191. https://doi.org/10.1038/s41598-019-45640-y

178. Zhang X, Yang Y, Su J, Zheng X, Wang C, Chen S, Liu J, Lv Y, Fan S, Zhao A, Chen T, Jia W, Wang X (2021) Age-related compositional changes and correlations of gut microbiome, serum metabolome, and immune factor in rats. GeroScience 43:709-725. https://doi.org/10.1007/s11357-020-00188-y

179. Wu CS, Muthyala SDV, Klemashevich C, Ufondu AU, Menon R, Chen Z, Devaraj S, Jayaraman A, Sun Y (2021) Age-dependent remodeling of gut microbiome and host serum metabolome in mice. Aging 13:6330-6345. https://doi.org/10.18632/aging. 202525

180. Gagliardi A, Totino V, Cacciotti F, Iebba V, Neroni B, Bonfiglio G, Trancassini M, Passariello C, Pantanella F, Schippa S (2018) Rebuilding the gut microbiota ecosystem. Int J Environ Res Public Health 15:1679. https://doi.org/10.3390/ijerph15081679

181. Bosco N, Noti M (2021) The aging gut microbiome and its impact on host immunity. Genes Immun. https://doi.org/10.1038/ s41435-021-00126-8

182. Moya A, Ferrer M (2016) Functional redundancy-induced stability of gut microbiota subjected to disturbance. Trends Microbiol 24:402-413. https://doi.org/10.1016/j.tim.2016.02.002

183. Bhatia-Dey N, Kanherkar RR, Stair SE, Makarev EO, Csoka AB (2016) Cellular senescence as the causal nexus of aging. Front Genet 7:13. https://doi.org/10.3389/fgene.2016.00013

Publisher's Note Springer Nature remains neutral with regard to jurisdictional claims in published maps and institutional affiliations. 